\title{
1 Environmental benchmarks for buildings: a critical 2 literature review
}

3 Trigaux D. ${ }^{1,2,3}$, Allacker $\mathrm{K}^{1}$, Debacker $\mathrm{W}^{2,3}$.

$41 \mathrm{KU}$ Leuven, Department of Architecture, Kasteelpark Arenberg 1/2431, 3001 Leuven, Belgium

52 EnergyVille, Thor Park 8310, 3600 Genk, Belgium

63 VITO, Unit Smart Energy \& Built Environment, Boeretang 200, 2400 Mol, Belgium

7 damien.trigaux@kuleuven.be,+3216321376

8 This article was published in the International Journal of Life Cycle Assessment (Springer 2020). The final 9 publication is available at https://link.springer.com/article/10.1007/s11367-020-01840-7 https://doi.org/10.1007/s11367-020-01840-7

\section{Abstract}

Purpose To reduce the environmental impact of the building sector, environmental targets considering the full life cycle of buildings can be supportive. In recent years various benchmarks based on Life Cycle Assessment (LCA) have been developed as part of regulations, labelling systems, sustainability rating tools and research studies. The objective of this paper is to critically analyse 23 existing benchmarking systems focusing on the benchmark methodology but also on the benchmark applications and communication.

Methods The critical literature review consists of two parts. In a first part, the choices related to the assessment method, functional equivalent, definition of benchmark values, benchmark scope, benchmark applications and benchmark communication are compared. In the second part, benchmark values are compiled from literature and statistically analysed.

Results and discussion The comparative analysis allows to identify the main approaches and methods used in benchmarking systems. For each evaluation aspect, the strengths and weaknesses of the various approaches are highlighted. The statistical analysis provides insight in the spread of benchmark values. Important variations are found between the literature sources which can be explained by differences in benchmark approach, scope, system boundaries and applications.

Conclusions Based on the comparative analysis, recommendations are formulated for the development of LCA benchmarks for the building sector. The results of the statistical analysis furthermore provide reference values which can be used for the validation of future benchmarks. For global warming, the statistical values for the full life cycle impacts (i.e. embodied and operational impacts) range from about 15 up to $35 \mathrm{~kg} \mathrm{CO}_{2}$ eq. $/ \mathrm{m}^{2}$.a. 
31 Keywords: Environmental targets, Life Cycle Assessment, Climate targets, Embodied impacts, Performance 32 classes. 


\section{Introduction}

The building sector has a major impact on the environment. In Europe, this sector is responsible for about $50 \%$ of the use of natural resources, $40 \%$ of the energy use and $16 \%$ of the water use (Ebert et al. 2011). Buildings are furthermore responsible for $36 \%$ of the total $\mathrm{CO}_{2}$ emissions in the EU (European Commission 2019). Life Cycle Assessment (LCA) is an internationally accepted and widely used method to assess and optimize the environmental impact of buildings over their entire life cycle. The European Commission (EC) recognises the relevance of considering the environmental impact of buildings from a life cycle perspective concerning raw material efficiency, construction waste and energy (European Commission 2011; European Commission 2012). The use of LCA to evaluate construction products and buildings is also recommended in the international standard ISO 21930 (ISO 2017) and European standards EN15804:2012+A2 (CEN 2019) and EN 15978:2011 (CEN 2012).

To enable the transition towards a sustainable built environment, the definition of environmental targets or benchmarks considering the full life cycle of buildings is seen as an important step. These LCA benchmarks will allow architects and building stakeholders to position themselves in the market and consequently to further push the construction sector in reducing its environmental impacts. According to the Product Environmental Footprint (PEF) guidance document (European Commission 2018), which describes the LCA method applied to products in the European Union, a benchmark is defined as a standard or point of reference against which any comparison can be made. In the building sector, building energy use benchmarks have been introduced in all EU member states in the context of the European Directive on the Energy Performance of Buildings (EPB) (European Union 2010). In contrast to the well-established energy benchmarks, the development and implementation of LCA benchmarks of buildings is still in its early stages (Lützkendorf and Balouktsi 2018). Since 2018, the life cycle environmental impact of new buildings in the Netherlands is restricted to a maximum value per $\mathrm{m}^{2}$ floor area per year (RVO 2019) and classes of environmental performance of residential buildings have been defined (W/E adviseurs 2014). In France a voluntary labelling system "E+/C-“ (République Française 2016) exists and Switzerland has defined a benchmark within the initiative of the "2000 Watt Society" (SIA 2017a; SIA 2017b). LCA benchmarks are furthermore integrated in sustainability rating tools such as BREEAM (BRE 2018), DGNB (DGNB GmbH 2018) and LEED (USGBC 2019). Next to the implementation of benchmarks in regulations, labels and rating tools, various research studies focused on the definition of environmental benchmarks for buildings (Zimmermann et al. 2005; König 2008; König and De Cristofaro 2012; EC 2013; Moschetti et al. 2015; Mair am Tinkhof et al. 2017; Lasvaux et al. 2017; Brejnrod et al. 2017; Simonen et al. 2017; Gervasio and Dimova 2018a; Rasmussen and Birgisdottir 2018; Lavagna et al. 2018; Schlegl et al. 2019; Chandrakumar et al. 2019; Rasmussen et al. 2019). 
The goal of this paper is to critically analyse existing benchmarking systems. The critical literature review consists of two parts. In the first part, choices related to the benchmark methodology, applications and communication are compared, highlighting the strengths and weaknesses of the various approaches. Based on this comparative analysis, recommendations are formulated for the development of environmental benchmarks. The recommendations do not focus on a specific audience but try to combine the perspective of both policy makers and building stakeholders (i.e. designers, engineers, LCA practitioners and project developers). As a result, policy aspects as well as the feasibility and user-friendliness of benchmarks are considered. The second part includes a compilation and statistical analysis of benchmark values available in literature, providing reference values for the validation of future LCA benchmarks.

This research is based on a literature review presented at the Sustainable Built Environment conference 2019 in Graz (Trigaux et al. 2019). Compared to the original study, this research is extended in terms of selected benchmarking systems and covered evaluation aspects. The compilation and statistical analysis of benchmark values is moreover added in the current study.

\section{Methods}

\subsection{Selected benchmarking systems}

Twenty-three representative benchmarking systems are selected for the critical analysis. These include benchmarks from regulations, labelling systems, sustainability ratings tools and research studies. The selection is based on existing review studies (Ganassali et al. 2016; VITO et al. 2018) and the experience of the authors within the international project IEA EBC Annex 72 (Frischknecht et al. 2019). The selection aims at providing a wide overview of possible approaches and methods. It does not reflect any a priori preference between the benchmarking systems. As the goal of this paper is to underpin the main methodological choices rather than providing an exhaustive overview of existing benchmarking studies, no systematic literature review has been done.

As regulatory tool, the legal requirements on the environmental performance of buildings in the Netherlands (“MilieuPrestatie Gebouwen" (MPG)) are evaluated (W/E adviseurs 2014; RVO 2019). Two labelling systems are selected: the French initiative "E+/C-" (République Française 2016) and the Swiss SIA Energy Efficiency Path (SIA 2040) (SIA 2017a; SIA 2017b). LCA benchmarks implemented as part of five well-known sustainability rating tools are analysed: BNB for offices, administrative buildings, educational buildings and laboratories (BMUB 2014; BMUB 2015; BMUB 2017), BREEAM Home Quality Mark (BRE 2018), CASBEE for Building (New Construction) (JSBC and IBEC 2014), DGNB for new buildings (DGNB GmbH 2018) and LEED for Building Design and Construction (USGBC 2019). Furthermore fifteen research studies focussing on the definition 
of environmental benchmarks for buildings are selected for an in-depth analysis (Zimmermann et al. 2005; König 2008; König and De Cristofaro 2012; EC 2013; Moschetti et al. 2015; Mair am Tinkhof et al. 2017; Lasvaux et al. 2017; Brejnrod et al. 2017; Simonen et al. 2017; Gervasio and Dimova 2018a; Rasmussen and Birgisdottir 2018; Lavagna et al. 2018; Schlegl et al. 2019; Chandrakumar et al. 2019; Rasmussen et al. 2019). Studies defining benchmarks at the level of building elements, such as (Hollberg et al. 2019), are not included in the literature review as the focus is on benchmarks at the building level.

\subsection{Evaluation aspects}

In order to critically analyse the benchmarking systems and identify the main approaches and methods, a list of evaluation aspects is defined based on existing methodological reports and literature reviews on LCA benchmarks (VTT 2012; Ganassali et al. 2016; VITO et al. 2018). Six main categories of aspects are considered for the comparative analysis, including various sub-aspects (see Table 1).

The first four categories are related to the benchmark methodology while the last two categories focus on benchmark applications and communication respectively. Based on this list of evaluation aspects a matrix is developed to compare the key data between the selected benchmarking systems and highlight similarities and differences among the methods. The data from the matrix are summarized in a number of tables which are discussed in section 3.1 .

\section{Table 1 here}

\subsection{Database of benchmark values}

The benchmark values defined in the selected benchmarking systems are compiled in a database. In this database benchmark values per environmental indicator are classified according to the geographical coverage, benchmark approach, typology, scope and applications in order to allow for data grouping and statistical analysis.

To enable comparisons, all data are converted to a similar reference unit expressed in impact per $\mathrm{m}^{2}$ floor area per year. Depending on the literature source, some benchmark values are therefore divided by the reported reference study period and/or floor area. As the definition of floor area may vary between the studies (see section 3.1.2), including data expressed in net floor area (NFA) and gross floor area (GFA), the benchmark values have been harmonized to GFA using a conversion factor of $0.8 \mathrm{~m}^{2}$ NFA per $\mathrm{m}^{2}$ GFA (European Union 2015). Furthermore, when no reference study period or floor area are reported, which is only the case in (Simonen et al. 2017) and (BRE 2018), default values of respectively 50 years and $50 \mathrm{~m}^{2}$ GFA per person for residential buildings are considered for the data harmonization. The latter is calculated as an average of conversion factors found in other benchmarking systems (Mair am Tinkhof et al. 2017; SIA 2017a; Brejnrod et al. 2017). The harmonization steps 
applied to the various benchmarking systems are summarized in supplementary materials (Table S.1). Despite the abovementioned harmonization steps, it should be mentioned that the differences in functional unit, scope and system boundaries are a source of uncertainty when comparing the benchmarks values.

Based on the analysed benchmarking systems, a total of 712 data points are collected. The distribution of the data points over the environmental indicators is shown in Fig. 1. Only the indicators with more than ten data points are visualized separately (others are grouped under the category "Other indicators"). The most represented indicators in the database are Global Warming Potential (GWP) (257 data points), followed by Non-Renewable Primary Energy demand (PEnr) (115 data points) and Total Primary Energy demand (PEtot) (85 data points). Concerning the covered life cycle stages, the compiled benchmark values mainly focus on embodied impacts (about $40 \%$ ) or consider the full building life cycle (about $40 \%$ ), i.e. both embodied and operational impacts. A smaller number of benchmark values (about 20\%) focus on operational impacts only, such as energy use, water use or user transport.

Fig. 1 here

\section{Results and discussion}

\subsection{Comparative analysis of benchmarking systems}

The results of the comparative analysis are presented according to the six main categories defined in section 2.2. For each evaluation aspect, the strengths and weaknesses of the different approaches are described and recommendations are formulated.

\subsubsection{Assessment method}

The LCA methods applied to assess the environmental impact in the various benchmarking systems are summarized in Table 2. The analysed benchmarks refer either to the international or European LCA standards (i.e. ISO 14040/14044 or EN 15804/15978), a national LCA method or a specific LCA guideline developed for benchmarking purposes.

Compared to the general nature of international and European standards, national LCA methods or LCA guidelines provide more specific guidance and rules. The latter moreover often include life cycle scenarios which are in line with the national or local context. As an example, the Dutch LCA method (SBK 2019) provides national scenarios for the transport of building materials to the construction site and the transport and waste treatment at the end-oflife. Defining prescriptive national LCA methods and guidelines improve reproducibility and comparability of results which are essential for benchmarking, especially when benchmarks are part of legal requirements.

Table 2 here 
In order to calculate the building LCA results, various LCA tools can be used (see Table 2). A distinction can be made between two types of tools: general LCA tools and building LCA tools. General LCA tools, such as GaBi and Simapro (PRé Consultants B.V. 2020; Thinkstep 2020a), are built from LCI data and can be used for an LCA of various types of products. These tools are mainly used in the benchmark research studies as they offer more flexibility and assessment possibilities. General LCA tools however require expert LCA knowledge which is often not available among building practitioners. Contrariwise, building LCA tools, such as eLCA, LEGEP or ELODIE (BBSR 2020; CSTB 2020; WEKA MEDIA 2020), are specifically developed for the building sector and are useroriented. These often provide a hierarchic assessment structure which facilitate the modelling of building elements and buildings. These tools are therefore better suited for the building practice and hence might be preferred to assess specific building projects against the benchmarks.

Depending on the benchmarking system considered, one specific tool or a list of several compliant tools may be applied for the assessment. Allowing the use of several tools, such as in MPG, E+/C-, BREEAM and DGNB, can foster the competition between tool developers. These are stimulated to provide better and more user-friendly tools as the building practitioner can choose which tool is the most suited for his particular needs. The main drawback is the need to implement a validation procedure to ensure the comparability of the LCA results between the different LCA tools.

Concerning the background data various LCI/LCA databases are used in the benchmarking systems (see Table 2). While benchmarks implemented in regulations, labels and rating tools mainly build on a national LCA database of generic and product specific data, such as the German ÖKOBAUDAT (BMI 2020) and French database INIES (Association HQE 2020), research studies often use a generic LCI database such as Ecoinvent (Ecoinvent centre 2020) and $\mathrm{GaBi}$ (Thinkstep 2020b). This difference is directly related to the theoretical nature of research studies.

\subsubsection{Functional equivalent}

As benchmarking systems are used for comparative purposes, these should clearly define the functional unit and system boundaries. Table 3 provides an overview of the reference units, reference study periods and geographical coverage of the benchmarking systems studied.

Table 3 here

Concerning the reference unit, benchmark values may be expressed per $\mathrm{m}^{2}$ of floor area, per occupant or for the whole building (or dwelling). Furthermore benchmarks may be reported for the whole reference study period or converted to annual values. The majority of analysed benchmarks are defined per $\mathrm{m}^{2}$ of floor area although the definition of floor area varies between the studies (i.e. gross or net floor area). 
A detailed description of the strengths and weaknesses of various reference units can be found in (Allacker 2010). An approach based on the floor area, which is commonly used in energy use benchmarks, allows to compare different building layouts and typologies. It is however less suited for comparing buildings with a varying amount of floor area per occupant, as the preference would go to larger buildings which often have a lower impact per $\mathrm{m}^{2}$ of floor area, although the absolute impact is higher. An analysis per occupant is then preferred but is less robust as the number of occupants may change during the service life of the building. An approach using the whole building as a reference is only relevant when the building design is fixed and only the impact of various material and service choices are investigated. It is therefore only appropriate in the context of internal benchmarks (see section 3.1.3).

Based on these strengths and weaknesses, the authors recommend to provide a combination of benchmark values expressed per $\mathrm{m}^{2}$ floor area and per occupant. A list of conventional factors for the conversion of surface-related to person-related benchmarks values could be included, as is the case in SIA 2040. It is moreover recommended to define clear rules on how to define the floor area (VITO et al. 2018), which should ideally be harmonized with the rules for energy performance benchmarks.

The reference study periods used in the analysed benchmarking systems vary from 20 to 120 years. Ten out of the 23 literature sources use a reference study period of 50 years. A short reference study period, such as 20 or 30 years, is more adapted to economic assessments as the focus is on rather short-term investments. From a sustainability point of view a long reference study period, such as 80 or 100 years, is preferred as it is more in line with the real service life of buildings and allows to include the impact of replacements and refurbishments and therefore to assess the benefits related to the durability of building components (VTT 2012). The level of uncertainty however increases with the considered study period as future processes and scenarios are difficult to predict. The authors hence recommend a reference study period of 50 or 60 years as a compromise.

Regarding the geographical coverage, the majority of benchmarking systems are defined at national level. Only three research studies focus on the European (EC 2013; Gervasio and Dimova 2018a; Lavagna et al. 2018) or international context (Simonen et al. 2017). Benchmarks at national level are recommended as this ensures that local conditions such as climate, seismic constraints, construction practice and culture, influencing the environmental impact, are considered (VITO et al. 2018). For large and geographically diverse countries, a further differentiation per region could also be required to include these local specificities.

A last important aspect related to the system boundaries are the building elements covered. An overview of the building elements included is given in Table 4, classified according to the nine main categories of the CI-SfB 
classification (Ray-Jones and Clegg 1978). Ten of the analysed literature sources cover a wide range of building elements, including the building substructure, structure, finishes and services. Others are limited to the space delimiting elements without considering the technical systems. In a few cases, the included building elements are not clearly specified.

To define the system boundaries the authors recommend to start from the perspective of the designer or architect. This means that all building elements that the designer or architect can influence shall be included (VITO et al. 2018). This includes at least the substructure, structure, finishes, services, fittings and external elements on the building site. The building elements included and excluded should be clearly stated in the documentation in order to avoid wrong interpretations which may negatively influence the comparability of the benchmark results.

Table 4 here

\subsubsection{Definition of benchmark values}

Table 5 provides an overview of the approaches to define benchmark values identified through the literature review. A first important difference noticed is the comparative base, distinguishing two groups: external and internal benchmarks (Ganassali et al. 2016). External benchmarks are representative values for the environmental impact of a category of buildings within the building stock and serve as comparative base for buildings from that category. In case of internal benchmarks, a baseline building with geometrical and context features similar to the project is defined and used as comparative base. The majority of the analysed benchmarking systems use external benchmarks; only CASBEE and LEED fall into the second group.

Compared to internal benchmarks, two main advantages of external benchmarks are identified (VITO et al. 2018). First, external benchmarks allow for a comparison between the environmental performance of the project and the building stock and hence allow for a positioning within the market. Second, the impact of the full design in terms of building geometry, material choices and energy performance can be assessed while internal benchmarks are limited to assess the influence of material choices. Internal benchmarks should hence only be preferred when there is a lack of data to model the impact of the building stock and derive representative external benchmark values or when the goal is only to assess material choices.

Table 5 here

In order to define external benchmark values, two approaches can be followed which are closely related to the data sources (VTT 2012). The first and most widespread one is a bottom-up approach consisting of values derived from a statistical analysis of the building stock. This can be done by analysing a set of representative real buildings, as in E+/C-, (König 2008) and (Lasvaux et al. 2017), or by defining virtual (generic) buildings or archetypes, as in 
MPG, BNB and (König and De Cristofaro 2012). A more recent alternative is to apply a data-driven procedure compiling the results of various LCA studies (Simonen et al. 2017; Schlegl et al. 2019). The second approach is a top-down approach which defines benchmarks based on global environmental goals or policy targets translated to the building sector. Examples of environmental goals are the greenhouse gases (GHG) reduction targets (Chandrakumar et al. 2019) or the Earth environmental carrying capacity (Brejnrod et al. 2017). To allocate the overall goals to the building sector, different procedures can be used including environmental pressure allocation (based on the current or projected share of environmental loads) or economic allocation (based on the share of consumer spending). The top-down approach is applied in three research studies (Zimmermann et al. 2005; Brejnrod et al. 2017; Chandrakumar et al. 2019). More rarely, a combined top-down and bottom-up approach is followed, as in SIA 2040 and (Mair am Tinkhof et al. 2017).

Both the bottom-up and top-down approaches have their strengths and weaknesses. The main strength of the bottom-up approach lies in the derivation of feasible benchmark values based on currently available construction methods and technologies. This approach however requires sufficient data to define representative reference buildings and cover market variations. The main advantage of the top-down approach is that it allows to derive long term target values to fulfil environmental goals and policy targets. The main drawback is that it implies the availability of global targets for the assessed impact indicators and an appropriate procedure to allocate these overall goals to the building sector. As both approaches provide complementary insights, a combined top-down and bottom-up approach is seen as the best way forward. Such hybrid approach allows to define long term target values (top-down) and to investigate their practical feasibility based on a statistical analysis of the building stock (bottom-up) which could be used as short term intermediate values.

Concerning the benchmark typology, the majority of the analysed systems combine different types of benchmark values. In general, these values can be classified in four types (VTT 2012):

- limit value: lowest value of an assessment scale (minimum acceptable performance);

- $\quad$ reference value: present state of the art (average or median value);

- best practice value: value reached in best practice, experimental or demonstration projects;

- $\quad$ target value: upper value of the assessment scale (highest theoretically possible level).

Limit and reference values can be characterized as short term values. Their strengths are to exclude buildings with high environmental impacts while addressing all stakeholders (level-playing field). It is expected that these values will however not lead to major environmental improvements and therefore require a regular update towards more severe benchmarks (VITO et al. 2018). Best practice and target values are characterized as medium or long term 
values. These values allow to steer towards an improved environmental performance and policy target. The main drawback is that these might not be feasible for all buildings due to lack of knowledge or technology (VITO et al. 2018). The use of a combination of at least two benchmark values to cover both short and long term objectives is therefore recommended. The authors moreover propose to follow a stepwise implementation approach to gradually evolve from current-state reference values towards more ambitious values in future.

\subsubsection{Benchmark scope}

The life cycle stages covered by the 23 benchmarking systems are described in Table 6. The scope is either limited to embodied impacts, e.g. in MPG, BREEAM and (Gervasio and Dimova 2018a), or cover the full building life cycle (i.e. embodied and operational impacts), e.g. in E+/C-, DGNB and (Lasvaux et al. 2017). Full life cycle benchmarks are often combined with sub-benchmarks or indicative values for embodied impacts and operational impacts.

While embodied impact benchmarks only focus on the impact of material use, full life cycle benchmarks allow for a global optimization of the environmental performance considering the trade-offs between embodied and operational impacts. For example, the improvement of the building insulation level results in an increase of embodied impacts from insulation materials and a decrease of operational impacts for energy use. Full life cycle benchmarks furthermore give more flexibility to architects to decide how to optimize their building design. The authors therefore recommend to define full life cycle benchmarks, to be combined with indicative benchmark values for embodied and operational impacts (e.g. energy use, water use) separately if desired. This could guide designers towards lower environmental impacts throughout the various life cycle stages.

Table 6 here

Table 7 provides an overview of the environmental indicators covered by the various systems studied. The majority of systems define benchmark values for one or more individual impact indicators, while a few rely on an aggregated impact indicator based on the weighting of individual impact indicators, i.e. MPG and BREEAM. As an example MPG relies on an aggregated impact indicator expressed in environmental cost. This aggregated impact indicator is calculated by multiplying 11 individual environmental impact indicators with their specific monetary value and adding these up to obtain the overall environmental cost (SBK 2019). In one research study (Zimmermann et al. 2005), a combination of individual and aggregated impact indicators was found.

A long list of individual impact indicators such as in DGNB can be difficult to handle, while an aggregated impact indicator is easier to understand and communicate to a non-scientific audience. Benchmarks per individual impact indicator however allow to focus on specific environmental issues which require urgent action such as for example 
global warming. If the LCA method includes the calculation of an aggregated impact score, the authors recommend to use this single score indicator for benchmarking. This should be combined with sub-benchmarks for the most relevant individual impact indicators in order to fulfil international sustainability goals such as the GHG emission reduction targets.

\section{Table 7 here}

Concerning the covered impact categories, most assessed indicators are related to the core impact categories defined in the European standards EN 15804:2012+A1 (CEN 2013). The Global Warming Potential is the only indicator covered by all analysed benchmarking systems. Only three benchmarking systems, i.e. MPG, (Brejnrod et al. 2017) and (Lavagna et al. 2018), include indicators which are part of the additional impact categories recommended by the recently revised version EN 15804:2012+A2 (CEN 2019). It is however expected that an increasing number of benchmark values for these additional impact categories will be developed in the near future when the revised CEN standard will become common practice.

\subsubsection{Benchmark applications}

The benchmarking systems analysed cover various building types and types of construction work (new construction, refurbishment and/or existing buildings), as presented in Table 8. Some benchmarking systems are limited to one or two building types while others are applicable to a wide range of types. Our recommendation for the development of future benchmarks is to use a stepwise approach starting with the most widespread types (i.e. residential and office buildings) which are then extended to other building types in subsequent steps.

The majority of the analysed benchmarking systems are limited to new construction. Only SIA 2040, (Gervasio and Dimova 2018a), (Lavagna et al. 2018) and (Zimmermann et al. 2005) include benchmark values for new construction, refurbishments and/or existing buildings. The latter should be preferred as the refurbishment of the existing building stock is seen as a policy priority for the coming years (European Commission 2020).

Table 8 here

\subsubsection{Benchmark communication}

Among the analysed benchmarking systems, three options can be distinguished for benchmark communication (see Table 9). The first option, which is followed by the majority of the research studies, is to directly communicate benchmark values (e.g. $\mathrm{kg} \mathrm{CO}_{2}$ eq.). The second option is to use performance classes (e.g. label A to E). The third option, which is applied in sustainability rating tools, is to calculate a total score based on the benchmark values. While benchmark values are more transparent and hence preferred from a scientific perspective and experts in the 
field, performance classes and scores are easier to communicate and hence preferred from a user perspective. The authors hence recommend a combination of both, as applied in MPG.

Table 9 here

3.2 Statistical analysis of benchmark values

This section focuses on the statistical analysis of the benchmark values collected from the selected literature sources. The eight most represented environmental indicators from the database (Fig. 1) are selected for an indepth analysis. The results for the Global Warming Potential (GWP) are shown in Fig. 2 while the results for the other environmental indicators can be found in supplementary materials (Fig. S.1, Fig. S.2, Fig. S.3, Fig. S.4, Fig. S.5, Fig. S.6 and Fig. S.7). The results are subdivided in embodied and full life cycle impacts. The full life cycle impacts include here the embodied impacts, impacts for operational energy use and operational water use when the latter is part of the benchmark scope (see Table 6). Furthermore, the results are presented per benchmark system and additionally grouped into three main categories to derive global trends, including residential buildings, non-residential buildings and the whole dataset of building types (“All buildings"). For GWP, a further differentiation of the results per building type, as indicated in Table 8, is included in supplementary materials (Fig. S.8)

Fig. 2 here

A number of observations can be formulated for all analysed environmental indicators. Firstly, there is a wide spread in benchmark values between the literature sources which can be explained by differences in benchmark approach, scope, system boundaries and intended applications. Furthermore, the definition of benchmarks values can be also influenced by policy and practical considerations. For example, in E+/C-, high (easy to fulfil) benchmark values for the embodied GWP impacts (see Fig. 2) have been chosen in an initial implementation stage in order to address all building stakeholders (level-playing field). Secondly, while some literature sources only provide a single value for each indicator, others provide a set of values covering various benchmark types (i.e. limit, reference, best-practice or target values) and/or building types. In that case, a wider spread of values can also be observed within one benchmarking system. Thirdly, the global trends for residential buildings show for most impact indicators lower benchmark values compared to non-residential buildings. As an example, the average benchmark value for the full life cycle GWP impacts is about 16 and $25 \mathrm{~kg} \mathrm{CO}_{2} \mathrm{eq} / \mathrm{m}^{2}$.a for residential and nonresidential buildings respectively. Fourthly, the spread in values is always higher when the full life cycle is considered compared to when only embodied impacts are taken into account. This can be explained by the 
differences in operational energy use between the building types and type of construction works (new construction versus existing buildings).

Based on the statistical analysis the median, lower and upper quartile values can be reported for both the embodied and full life cycle benchmark values (Table S.2 in supplementary materials). These statistical values can be used for the validation of future benchmarking systems. As an example, the quartile values for Global Warming Potential for the main category "All buildings" varies from 4.9 to $8.6 \mathrm{~kg} \mathrm{CO} 2 \mathrm{eq} / \mathrm{m}^{2}$. a for the embodied benchmark values and from 14.0 to $33.7 \mathrm{~kg} \mathrm{CO} 2 \mathrm{eq} / \mathrm{m}^{2}$.a for the full life cycle values. These results are of the same order of magnitude as the global trends reported by (Röck et al. 2020) based on the compilation of 238 LCA case studies from literature. In this study, the quartile values for new buildings (both residential and offices) ranges from approximately 3.3 to $13.3 \mathrm{~kg} \mathrm{CO}$ eq/m².a and 10.5 to $45.1 \mathrm{~kg} \mathrm{CO} 2 \mathrm{eq} / \mathrm{m}^{2}$.a for the embodied and full life cycle impacts respectively.

\section{Conclusions}

In this study 23 benchmarking systems were critically analysed through a comparison of the choices related to the benchmark methodology, applications and communication and a statistical analysis of the provided benchmark values. Based on the comparative analysis, seven main recommendations for the development of future benchmarks are formulated. First, the assessment method used for the benchmarking purpose should be clearly defined in order to ensure the reproducibility and comparability of the LCA results. It is therefore recommended to provide a highly prescriptive LCA method, compliant LCA tools and a comprehensive LCA database of generic and specific data. The preference should furthermore go to national methods, tools and databases which are better in line with the local context and constraints. Second, a clear definition of the functional equivalent is recommended, in terms of reference unit, reference study period and building elements to be included. The preference goes to a combination of benchmark values expressed both per $\mathrm{m}^{2}$ floor area and per occupant and a reference study period of 50 or 60 years. The benchmark should furthermore cover all building elements that the designer or architect can influence. Third, a combined top-down and bottom-up approach for defining benchmarks is recommended to ensure that on the long run benchmark values are in line with long term policy targets but on the short term are feasible based on available construction methods and technologies. Fourth, the benchmark system should include different performance levels (from limit to target values) to cover both these short term and long term objectives. A transition path from the short term limit or reference benchmark values to the long term target benchmark values should be defined. Fifth, the benchmark scope should be flexible in terms of life cycle stages and environmental indicators. This means a combination of full life cycle benchmarks and indicative values 
for embodied and operational impacts but also a combination of aggregated indicator and indicative values for individual impact indicators is recommended. Sixth, the benchmarks should in a first phase at least cover the most widespread building types and be applicable to both new construction, refurbishments and existing buildings. Finally, benchmarks should be communicated in a transparent and user-friendly way based on a combination of benchmark values and performance classes.

Based on the statistical analysis, insight is gained in the spread of the benchmark values showing important variations between the literature sources, which is directly related to the differences in terms of benchmark approach, scope, system boundaries and applications. Reference values (i.e. median, lower and upper quartile) are calculated which can be used to validate future benchmark values.

\section{References}

Allacker K (2010) Sustainable building, The development of an evaluation method. PhD dissertation, KU Leuven Architectural Institute of Japan AIJ-LCA\&LCW_ver.5.00

Architectural Institute of Japan 2005 Industrial Input-Output Table

Association HQE (2020) INIES database. www.inies.fr. Accessed 20 Jan 2020

Association HQE (2012) Specific rules for the environmental assessment of buildings - version of June 2012 for the HQE Performance Pilot test 2012

Association P.E.P (2020) PEP ecopassport program. www.pep-ecopassport.org. Accessed 24 Jan 2020

BBSR (2020) eLCA. https://www.bauteileditor.de/. Accessed 22 Jan 2020

BMI (2020) ÖKOBAUDAT. www.oekobaudat.de/en. Accessed 22 Jan 2020

BMI (2015) Bilanzierungsregeln für die Erstellung von Ökobilanzen - version 2015

BMUB (2014) Bewertungssystem Nachhaltiges Bauen (BNB) - Neubau Laborgebäude - version 2014

BMUB (2015) Bewertungssystem Nachhaltiges Bauen (BNB) - Büro-und Verwaltungsgebäude - version 2015

BMUB (2017) Bewertungssystem Nachhaltiges Bauen (BNB) - Unterrichtsgebäude - version 2017

BRE (2018) Home Quality Mark ONE - Technical Manual - England, Scotland \& Wales

BRE, AEC3, IES, WD Re-Thinking Ltd, Whole Life LTD (2020a) IMPACT compliant tools. http://www.impactwba.com/page.jsp?id=1. Accessed 22 Jan 2020

BRE, IES, Whole Life LTD, AEC3, WD Re-Thinking Ltd (2020b) IMPACT database. www.impactwba.com. Accessed 22 Jan 2020

Brejnrod KN, Kalbar P, Petersen S, Birkved M (2017) The absolute environmental performance of buildings. Build Environ 119:87-98 . https://doi.org/10.1016/j.buildenv.2017.04.003

CEN (ed) (2019) EN 15804:2012+A2 Sustainability of construction works - Environmental product declaration Core rules for the product category of construction products 
CEN (ed) (2012) EN 15978:2011 Sustainability of construction works - Assessment of environmental performance of buildings - Calculation method

CEN (ed) (2013) EN 15804:2012+A1 Sustainability of construction works - Environmental product declaration Core rules for the product category of construction products

Chandrakumar C, McLaren SJ, Dowdell D, Jaques R (2019) A top-down approach for setting climate targets for buildings: the case of a New Zealand detached house. IOP Conf Ser Earth Environ Sci 323:012183 . https://doi.org/10.1088/1755-1315/323/1/012183

CSTB (2020) ELODIE. https://logiciels.cstb.fr/batiments-et-villes-durables/performancesenvironnementales/elodie/. Accessed 17 Aug 2016

DGNB (2018) Life Cycle Assessments- a guide on using the LCA

DGNB (2020) ESUCO database

DGNB GmbH (2018) DGNB system - New buildings criteria set - version 2018

Ebert T, Essig N, Hauser G (2011) Green building certification systems: assessing sustainablility, international system comparison, economic impact of certifications. Edition Detail: Institut für international Architektur-Dokumentation, München

EC (2013) Open House - Assessment Guideline - Version 1.2 New Office Buildings

Ecoinvent centre (2020) Ecoinvent. www.ecoinvent.org. Accessed 20 Jan 2020

European Commission (2019) Energy efficiency in buildings. https://ec.europa.eu/energy/en/topics/energyefficiency/buildings. Accessed 2 Mar 2019

European Commission (2011) Communication from the European Commission - Roadmap to a Resource Efficient Europe

European Commission (2012) Communication from the European Commission - Innovating for Sustainable Growth: A Bio-economy for Europe

European Commission (2018) Product Environmental Footprint Category Rules Guidance - Version 6.3

European Commission (2020) Long-term renovation strategies. https://ec.europa.eu/energy/topics/energyefficiency/energy-efficient-buildings/long-term-renovation-strategies_en. Accessed 18 May 2020

European Commission (2013) EeBGuide - Operational Guidance for Life Cycle Assessment Studies of the Energy Efficient Buildings Initiative, Online InfoHub. http://www.eebguide.eu/. Accessed 16 Mar 2017

European Union (2010) Directive 2010/31/EU on the energy performance of buildings

European Union (2015) Commision Directive (EU) 2015/996 of 19 May 2015 establishing common noise assessment methods according to Directive 2002/49/EC of the European Parliament and of the Council

Frischknecht R, Balouktsi M, Lützkendorf T, Aumann A, Birgisdottir H, Ruse EG, Hollberg A, Kuittinen M, Lavagna M, Lupišek A, Passer A, Peuportier B, Ramseier L, Röck M, Trigaux D, Vancso D (2019) Environmental benchmarks for buildings: needs, challenges and solutions-71st LCA forum, Swiss Federal Institute of Technology, Zürich, 18 June 2019. Int J Life Cycle Assess 24:2272-2280 . https://doi.org/10.1007/s11367-019-01690-y

Ganassali S, Lavagna M, Campioli A (2016) LCA benchmarks in building's environmental certification systems. Albufeira, Portugal

Gervasio H, Dimova S (2018a) Environmental benchmarks for buildings. EC-JRC, Ispra 
Gervasio H, Dimova S (2018b) Model for Life Cycle Assessment (LCA) of buildings. EC-JRC, Ispra

HOINKA GMBH (2020) oekobilanz-bau.de. In: HOINKA. https:/www.oekobilanz-bau.de/. Accessed 22 May 2020

Hollberg A, Lützkendorf T, Habert G (2019) Top-down or bottom-up? - How environmental benchmarks can support the design process. Build Environ 153:148-157 . https://doi.org/10.1016/j.buildenv.2019.02.026

IBO (2020a) baubook eco2soft. https://www.baubook.info/eco2soft/. Accessed 22 Jan 2020

IBO (2020b) Baubook. www.baubook.info. Accessed 24 Jan 2020

ISO (ed) (2017) ISO 21930 - Sustainability in buildings and civil engineering works - Core rules for environmental product declarations of construction products and services

ISO (ed) (2006a) Environmental management - Life cycle assessment - Requirements and guidelines (ISO 14044:2006)

ISO (ed) (2006b) Environmental management - Life cycle assessment - Principles and framework (ISO 14040:2006)

JSBC, IBEC (2014) CASBEE for Building (New Construction) - Technical Manual (2014 Edition)

KBOB, eco-bau, IPB (2016) Données des écobilans dans la construction 2009/1:2016

König H (2008) Orientierungswerte für die Bewertung von Hochbauten erste Stufe: Bürogebäude

König H, De Cristofaro ML (2012) Benchmarks for life cycle costs and life cycle assessment of residential buildings. Build Res Inf 40:558-580 . https://doi.org/10.1080/09613218.2012.702017

Landgraf B, Krimmling J, Müller H (2015) Entwicklung einer Methodik zur Festlegung von Benchmarks für LCA und LCC im Rahmen der BNB-Systementwicklung - BNB-Referenzmodell - Endbericht

Lasvaux S, Lebert A, Achim F, Grannec F, Hoxha E, Nibel S, Schiopu N, Chevalier J (2017) Towards guidance values for the environmental performance of buildings: application to the statistical analysis of 40 lowenergy single family houses' LCA in France. Int J Life Cycle Assess 22:657-674 . https://doi.org/10.1007/s11367-016-1253-z

Lavagna M, Baldassarri C, Campioli A, Giorgi S, Dalla Valle A, Castellani V, Sala S (2018) Benchmarks for environmental impact of housing in Europe: Definition of archetypes and LCA of the residential building stock. Build Environ 145:260-275 . https://doi.org/10.1016/j.buildenv.2018.09.008

Lebert A, Lasvaux S, Grannec F, Nibel S, Achim F, Schiopu N (2013) Capitalisation des résultats de l'expérimentation HQE Performance - Analyse statistique - Action 22 - Rapport Final. CSTB, Paris

Lützkendorf T, Balouktsi M (2018) Principles for the development and use of benchmarks for life-cycle related environmental impacts of buildings. In: Life-Cycle Analysis and Assessment in Civil Engineering Towards an Integrated Vision. CRC Press/Balkema, Ghent, Belgium, pp 783-790

Mair am Tinkhof O, Strasser H, Prinz T, Herbst S, Schuster M, Tomschy R, Figl H, Fellner M, Ploß M, Roßkopf T (2017) Richt- und Zielwerte für Siedlungen zur integralen Bewertung der limaverträglichkeit von Gebäuden und Mobilitätsinfrastruktur in Neubausiedlungen. bmvit, Wien

Moschetti R, Mazzarella L, Nord N (2015) An overall methodology to define reference values for building sustainability parameters. Energy Build 88:413-427 . https://doi.org/10.1016/j.enbuild.2014.11.071

PRé Consultants B.V. (2020) SimaPro. In: SimaPro. https://simapro.com/. Accessed 10 Sep 2019 
Rasmussen FN, Birgisdottir H (2018) Life cycle assessment benchmarks for Danish office buildings. In: LifeCycle Analysis and Assessment in Civil Engineering - Towards an Integrated Vision. CRC Press/Balkema, Ghent, Belgium, pp 815-821

Rasmussen FN, Ganassali S, Zimmermann RK, Lavagna M, Campioli A, Birgisdóttir H (2019) LCA benchmarks for residential buildings in Northern Italy and Denmark - learnings from comparing two different contexts. Build Res Inf 47:833-849 . https://doi.org/10.1080/09613218.2019.1613883

Ray-Jones A, Clegg D (1978) CI/SfB Construction Indexing Manual. RIBA Publications Ltd, London

République Française (2016) Référentiel "Energie-Carbone” pour les bâtiments neufs - Niveaux de performance "Energie-Carbone" pour les bâtiments neufs

République Française (2017) Référentiel "Energie-Carbone" pour les bâtiments neufs - Méthode d'évaluation de la performance énergétique et environnementale des bâtiments neufs

République Française (2019) List of software tools available E+/C-. http://www.batimentenergiecarbone.fr/en/list-of-software-tools-available-a20.html. Accessed 20 Jan 2020

Röck M, Saade MRM, Balouktsi M, Rasmussen FN, Birgisdottir H, Frischknecht R, Habert G, Lützkendorf T, Passer A (2020) Embodied GHG emissions of buildings - The hidden challenge for effective climate change mitigation. Appl Energy 258:114107 . https://doi.org/10.1016/j.apenergy.2019.114107

RVO (2019) MilieuPrestatie Gebouwen. www.rvo.nl/onderwerpen/duurzaam-ondernemen/gebouwen/wetten-enregels-gebouwen/nieuwbouw/milieuprestatie-gebouwen. Accessed 15 Nov 2019

SBi (2020) LCAbyg. https://lcabyg.dk/. Accessed 22 Jan 2020

SBK (2019) Bepalingsmethode Milieuprestatie Gebouwen en GWW-werken - versie 3.0

SBK (2020a) Validated tools for the Ducth LCA method. In: Natl. Milieu Database. https://milieudatabase.nl/milieuprestatie/rekeninstrumenten/. Accessed 20 Jan 2020

SBK (2020b) Nationale Milieudatabase. In: Natl. Milieudatabase. https://milieudatabase.nl/. Accessed 20 Jan 2020

Schlegl F, Gantner J, Traunspurger R, Albrecht S, Leistner P (2019) LCA of buildings in Germany: Proposal for a future benchmark based on existing databases. Energy Build 194:342-350 . https://doi.org/10.1016/j.enbuild.2019.04.038

SIA (2017a) SIA 2040 - Energy Efficiency Path. Zurich

SIA (2017b) SIA - Effizienzpfad Energie - Korrigenda C1 zum Merkblatt SIA 2040:2017. Zurich

SIA (2010) SIA 2032 - Graue Energie von Gebäude. Zurich

SIA (2020) Outil SIA 2040 relatif à la voie SIA vers 1'efficacité énergétique. https:/www.energytools.ch/index.php/fr/telecharger/logiciels/download/7-logiciels/67-tool-sia-2040-f. Accessed 22 Jan 2020

SIA (2018) Dokumentation D 0258 - Ergänzungen und Fallbeispiele zum Merkblatt SIA 2040:2017. Zurich

Simonen K, Rodriguez BX, De Wolf C (2017) Benchmarking the Embodied Carbon of Buildings. Technol Des 1:208-218 . https://doi.org/10.1080/24751448.2017.1354623

t.h.e. Software GmbH (2005) OGIP (Optimization of construction costs, energy consumption and environmental impact of buildings). http://www.the-software.de/

Thinkstep (2020a) GaBI software. www.gabi-software.com. Accessed 22 Jan 2020 
Thinkstep (2020b) GaBi LCA Database. www.gabi-software.com/databases. Accessed 24 Jan 2020

Trigaux D, Allacker K, Debacker W (2019) Critical analysis of environmental benchmarks for buildings. IOP Conf Ser Earth Environ Sci 323: . https://doi.org/10.1088/1755-1315/323/1/012031

USGBC (2019) LEED v4 for Building Design and Construction

VITO, KU Leuven, TU Graz (2018) PEF4Buildings - Study on the application of the PEF Method and related guidance documents to a newly office building - Deliverable D4: Proposal for approach for benchmark and classes of performance for new office buildings

VTT (2012) Sustainability and performance assessment and benchmarking of building - Final report. VTT Technology, Espoo

W/E adviseurs (2014) Onderzoek "Bepaling kwaliteitsniveaus milieuprestatie van woonfuncties.” Ministerie van Binnenlandse Zaken en Koningsrelaties, directie Bouwen, Utrecht

WEKA MEDIA (2020) LEGEP Software. www.legep.de. Accessed 23 Jul 2019

Zimmermann M, Althaus H-J, Haas A (2005) Benchmarks for sustainable construction. Energy Build 37:11471157 . https://doi.org/10.1016/j.enbuild.2005.06.017 
Tables

555 Table 1 Evaluation aspects.

\begin{tabular}{ll}
\hline Main categories & Sub-aspects \\
\hline Assessment method & LCA method \\
& LCA tool \\
& LCA database \\
\hline Functional equivalent & Reference unit \\
& Reference study period \\
& Geographical coverage \\
\hline Definition of benchmark values & Building elements included \\
\hline Benchmark scope & Comparative base \\
& Benchmark approach \\
\hline Benchmark applications & Benchmark typology \\
\hline Benchmark communication & Sources for benchmark \\
\hline
\end{tabular}

556 
Table 2 LCA method, tool and database.

\begin{tabular}{|c|c|c|c|}
\hline Benchmark system & LCA method & LCA tool & LCA database \\
\hline MPG & $\begin{array}{l}\text { National LCA method: Bepalingsmethode } \\
\text { Milieuprestatie Gebouwen en GWW-werken (SBK } \\
\text { 2019) }\end{array}$ & $\begin{array}{l}\text { List of compliant building LCA tools: GPR Gebouw } \\
\text { / Bouwbesluit, MPGCalc, MPRI MPG-software and } \\
\text { One Click LCA (SBK 2020a) }\end{array}$ & $\begin{array}{l}\text { National LCA database (generic and specific data): } \\
\text { Nationale Milieudatabase (SBK 2020b) }\end{array}$ \\
\hline $\mathrm{E}+/ \mathrm{C}-$ & $\begin{array}{l}\text { National LCA method: Méthode d'évaluation de la } \\
\text { performance énergétique et environnementale des } \\
\text { bâtiments neufs (République Française 2017) }\end{array}$ & $\begin{array}{l}\text { List of compliant building LCA tools: ClimaWin, } \\
\text { OneClick LCA, ELODIE, novaEQUER, } \\
\text { ThermACV, Béa, ArchiWIZARD, Vizcab and } \\
\text { COCON (République Française 2019) }\end{array}$ & $\begin{array}{l}\text { National LCA database (generic and specific data): } \\
\text { INIES (Association HQE 2020) }\end{array}$ \\
\hline SIA 2040 & National LCA method: SIA 2032 (SIA 2010) & $\begin{array}{l}\text { Building LCA tool: Outil SIA } 2040 \text { relatif à la voie } \\
\text { SIA vers l'efficacité énergétique (SIA 2020) }\end{array}$ & $\begin{array}{l}\text { National LCA database (generic data): Données des } \\
\text { écobilans dans la construction 2009/1:2016 (KBOB } \\
\text { et al. 2016) }\end{array}$ \\
\hline BNB & $\begin{array}{l}\text { LCA guideline: Bilanzierungsregeln für die } \\
\text { Erstellung von Ökobilanzen (BMI 2015) }\end{array}$ & Building LCA tool: eLCA (BBSR 2020) & $\begin{array}{l}\text { National LCA database (generic and specific data): } \\
\text { ÖKOBAUDAT (BMI 2020) }\end{array}$ \\
\hline BREEAM & EN 15804 (CEN 2013) & $\begin{array}{l}\text { List of compliant building LCA tools: IES, } \\
\text { eToolLCD and OneClick LCA (BRE et al. 2020a) }\end{array}$ & $\begin{array}{l}\text { National LCA database (generic data): IMPACT } \\
\text { database (BRE et al. 2020b) }\end{array}$ \\
\hline CASBEE & $\begin{array}{l}\text { LCA guideline: AIJ-LCA\&LCW_ver } 5.00 \\
\text { (Architectural Institute of Japan) }\end{array}$ & $\begin{array}{l}\text { Building LCA tool: CASBEE Life Cycle CO2 } \\
\text { calculation sheet (JSBC and IBEC 2014) }\end{array}$ & $\begin{array}{l}\text { Input-Output table (generic data): } 2005 \text { Industrial } \\
\text { Input-Output Table (Architectural Institute of Japan) }\end{array}$ \\
\hline DGNB & EN 15978 (CEN 2012) & $\begin{array}{l}\text { List of compliant building LCA tools: CAALA, } \\
\text { eLCA, LEGEP, oekobilanz-bau.be and SBS online } \\
\text { tool (DGNB 2018) }\end{array}$ & $\begin{array}{l}\text { - National LCA database (generic and specific } \\
\text { data): ÖKOBAUDAT (BMI 2020) } \\
\text { - } \quad \text { EPD data from EPD online tool and ECO } \\
\text { platform (DGNB 2018) }\end{array}$ \\
\hline LEED & ISO 14044 (ISO 2006a) & Not specified & LCA data compliant with ISO 14044 (ISO 2006a) \\
\hline Brejnrod et al. 2017 & ISO 14040 (ISO 2006b) & General LCA tool: GaBi (Thinkstep 2020a) & $\begin{array}{l}\text { - } \quad \text { LCI database (generic data): Ecoinvent version } \\
2.2 \text { (Ecoinvent centre 2020) } \\
\text { - } \quad \text { EPD data }\end{array}$ \\
\hline Chandrakumar et al. 2019 & EN 15978 (CEN 2012) & Not specified & Not specified \\
\hline Gervasio and Dimova 2018 & $\begin{array}{l}\text { LCA guideline: Model for Life Cycle Assessment } \\
\text { (LCA) of buildings (Gervasio and Dimova 2018b) }\end{array}$ & General LCA tool: GaBi (Thinkstep 2020a) & $\begin{array}{l}\text { LCI database (generic data): GaBi version } 8.6 \\
\text { (Thinkstep 2020b) }\end{array}$ \\
\hline König 2008 & ISO 14040 (ISO 2006b) & Building LCA tool: LEGEP (WEKA MEDIA 2020) & $\begin{array}{l}\text { - } \quad \text { LCI database (generic data): Ecoinvent version } \\
\text { 2.0 (Ecoinvent centre 2020) } \\
\text { - Data from industry }\end{array}$ \\
\hline $\begin{array}{l}\text { König and De Cristofaro } \\
2012\end{array}$ & ISO 14040-44 (ISO 2006b; ISO 2006a) & Building LCA tool: LEGEP (WEKA MEDIA 2020) & $\begin{array}{l}\text { National LCA database (generic and specific data): } \\
\text { ÖKOBAUDAT (BMI 2020) }\end{array}$ \\
\hline
\end{tabular}


Lasvaux et al. 2017

EN 15978 (CEN 2012), EeB Guide (European

Commission 2013) and HQE guidance documents

(Association HQE 2012)

Lavagna et al. 2018

EN 15978 (CEN 2012)

Mair am Tinkhof et al. 2017 EN 15978 (CEN 2012)

Moschetti et al. 2015

ISO 14040-44 (ISO 2006b; ISO 2006a)

Open House (EC 2013)

EN 15978 (CEN 2012)

Rasmussen and Birgisdottir $\quad$ EN 15978 (CEN 2012)

2018

Rasmussen et al. 2019 (1)

ISO 14040-44 (ISO 2006b; ISO 2006a) and EN 15978 (CEN 2012)

Rasmussen et al. 2019 (2) $\quad$ ISO 14040-44 (ISO 2006b; ISO 2006a) and EN 15978 (CEN 2012)

Schlegl et al. 2019

EN 15978 (CEN 2012)

Simonen et al. 2017

Zimmermann et al. 2005
Various LCA methods ${ }^{\mathrm{b}}$

Not specified
Building LCA tool: ELODIE (CSTB 2020)

General LCA tool: SimaPro (PRé Consultants B.V. 2020)

Building LCA tool: eco2soft (IBO 2020a)

General LCA tool: SimaPro (PRé Consultants B.V. 2020)

Not specified

Building LCA tool: LCAbyg (SBi 2020)

Excel spreadsheet

Building LCA tool: LCAbyg (SBi 2020)

Building LCA tool: oekobilanz-bau.be (HOINKA GMBH 2020)

Various LCA tools ${ }^{\mathrm{b}}$

Building LCA tool: OGIP (t.h.e. Software GmbH 2005)
- National LCA database (generic and specific data): INIES (Association HQE 2020)

- EPD data: PEP EPD (Association P.E.P 2020)

- LCI database (generic data): Ecoinvent version 2.01 (Ecoinvent centre 2020)

LCI database (generic data): Ecoinvent version 3.2 (Ecoinvent centre 2020)

National LCA database (generic and specific data): Baubook (IBO 2020b)

LCI database (generic data): Ecoinvent version 2.2 (Ecoinvent centre 2020)

European LCA database (generic data): ESUCO (DGNB 2020)

National LCA database (generic and specific data): Danish adapted version of ÖKOBAUDAT 2016 (BMI 2020)

LCI database (generic data): Ecoinvent version 3.3 (Ecoinvent centre 2020)

National LCA database (generic and specific data): Danish adapted version of ÖKOBAUDAT 2016 (BMI 2020)

National LCA database (generic and specific data): ÖKOBAUDAT (BMI 2020)

Various LCA databases ${ }^{\mathrm{b}}$

LCI database (generic data): Ecoinvent version 1.1 (Ecoinvent centre 2020)

${ }^{a}$ The study includes a comparison of benchmarks for residential buildings in Northern Italy (1) and Denmark (2).

${ }^{b}$ The benchmark values are based on the compilation of results from existing LCA studies with their own LCA methods, tools and databases. 
Table 3 Reference units, reference study periods and geographical coverage.

\begin{tabular}{|c|c|c|c|}
\hline Benchmark system & Reference unit & Reference study period & Geographical coverage \\
\hline MPG & $\mathrm{m}^{2}$ GFA per year & $\begin{array}{l}75 \text { years (residential) - } 50 \\
\text { years (non-residential) }\end{array}$ & The Netherlands \\
\hline $\mathrm{E}+/ \mathrm{C}-$ & $\mathrm{m}^{2} \mathrm{NFA}$ & 50 years & France \\
\hline SIA 2040 & $\mathrm{~m}^{2}$ heated GFA per year & No reference study period ${ }^{a}$ & Switzerland \\
\hline $\mathrm{BNB}$ & $\mathrm{m}^{2}$ NFA per year & 50 years & Germany \\
\hline BREEAM & Occupant & 60 years & United Kingdom \\
\hline CASBEE & $\mathrm{m}^{2}$ floor area per year & 30,60 or 90 years $^{\mathrm{b}}$ & Japan \\
\hline DGNB & $\mathrm{m}^{2} \mathrm{NFA}$ per year & 50 years & Germany \\
\hline LEED & Building & At least 60 years & United States \\
\hline Brejnrod et al. 2017 & Dwelling per year & 50 years & Denmark \\
\hline Chandrakumar et al. 2019 & $\begin{array}{l}\text { Dwelling, occupant and } \mathrm{m}^{2} \mathrm{NFA} \\
\text { (per year) }\end{array}$ & 90 years & New Zealand \\
\hline Gervasio and Dimova 2018 & $\mathrm{~m}^{2}$ GFA per year & 20,30 or 40 years & Europe \\
\hline König 2008 & $\mathrm{~m}^{2}$ NFA per year & 80 years & Germany \\
\hline $\begin{array}{l}\text { König and De Cristofaro } \\
2012\end{array}$ & $\mathrm{~m}^{2} \mathrm{NFA}$ per year & 50 years & Germany \\
\hline Lasvaux et al. 2017 & $\mathrm{~m}^{2} \mathrm{NFA}$ per year & 50 years & France \\
\hline Lavagna et al. 2018 & $\begin{array}{l}\text { Dwelling, occupant and } \mathrm{m}^{2} \text { floor } \\
\text { area per year }\end{array}$ & 100 years & Europe \\
\hline Mair am Tinkhof et al. 2017 & $\begin{array}{l}\text { Occupant and } \mathrm{m}^{2} \text { heated GFA per } \\
\text { year }\end{array}$ & 100 years & Austria \\
\hline Moschetti et al. 2015 & $\mathrm{~m}^{2}$ GFA per year & 50 years & Italy \\
\hline Open House (EC 2013) & $\mathrm{m}^{2}$ NFA per year & 50 years & Europe \\
\hline $\begin{array}{l}\text { Rasmussen and Birgisdottir } \\
2018\end{array}$ & $\mathrm{~m}^{2}$ heated GFA per year & 80 years & Denmark \\
\hline Rasmussen et al. $2019(1)^{\mathrm{d}}$ & $\mathrm{m}^{2}$ heated GFA per year & 100 years & Northern Italy \\
\hline Rasmussen et al. $2019(2)^{\mathrm{d}}$ & $\mathrm{m}^{2}$ GFA per year & 120 years & Denmark \\
\hline Schlegl et al. 2019 & $\mathrm{~m}^{2} \mathrm{NFA}$ per year & 50 years & Germany \\
\hline Simonen et al. 2017 & $\mathrm{~m}^{2}$ floor area & $\begin{array}{l}\text { Various reference study } \\
\text { periods }^{\mathrm{e}}\end{array}$ & International \\
\hline Zimmermann et al. 2005 & $\mathrm{~m}^{2}$ heated GFA per year & Not specified & Switzerland \\
\hline \multicolumn{4}{|c|}{$\begin{array}{l}\text { a Embodied emissions of building components are converted into values per year on the basis of their amortisation period. } \\
\text { b The reference study period depends on the building function and deterioration countermeasure grades. } \\
\text { c A sensitivity analysis is done for a reference study period of } 100 \text { years. } \\
\text { d The study includes a comparison of benchmarks for residential buildings in Northern Italy (1) and Denmark (2). } \\
\text { e The benchmark values are based on the compilation of results from existing LCA studies with their own reference study } \\
\text { period. }\end{array}$} \\
\hline
\end{tabular}


Table 4 Building elements included.

\begin{tabular}{|c|c|c|c|c|c|c|c|c|c|c|c|c|c|c|c|c|c|c|c|c|c|c|c|c|c|c|c|c|c|}
\hline \multirow[b]{2}{*}{ Benchmark : } & \multicolumn{29}{|c|}{ Building elements according to CI-SfB classification (Ray-Jones and Clegg 1978) } \\
\hline & 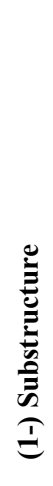 & 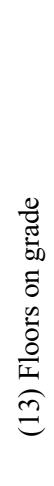 & 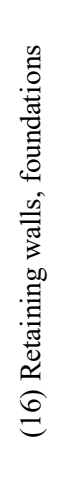 & 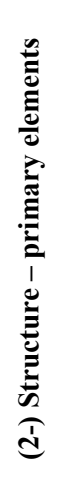 & 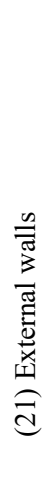 & 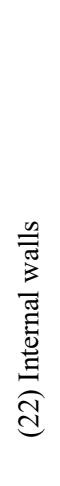 & 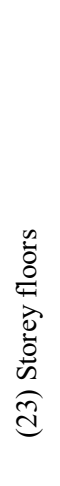 & 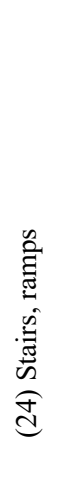 & 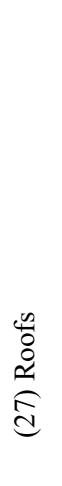 & 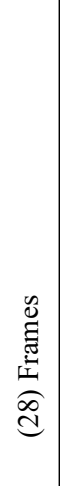 & 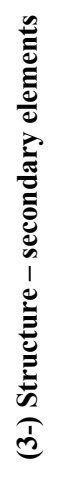 & 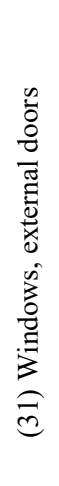 & 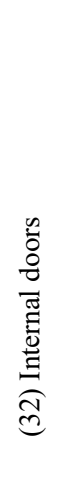 & 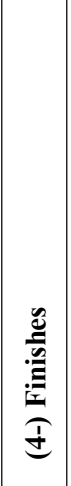 & 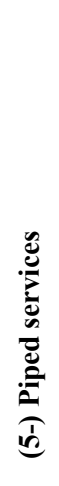 & 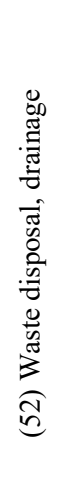 & 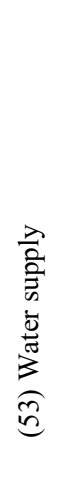 & 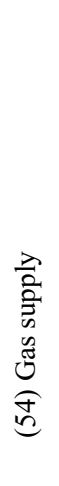 & 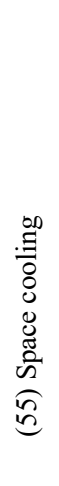 & 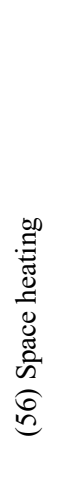 & 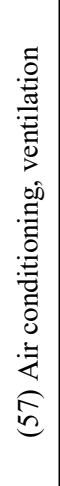 & 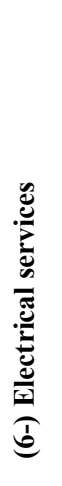 & 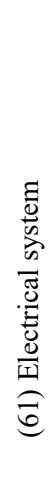 & 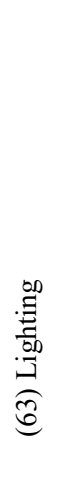 & 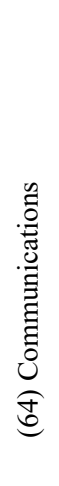 & 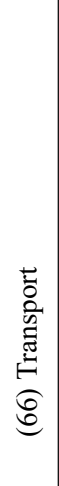 & 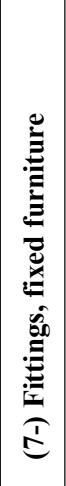 & 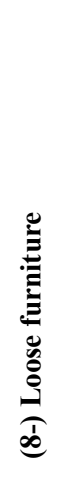 & ฮે \\
\hline MPG & & $\mathrm{X}$ & $\mathrm{X}$ & & $\mathrm{X}$ & $\mathrm{X}$ & $\mathrm{X}$ & $\mathrm{X}$ & $\mathrm{X}$ & $\mathrm{X}$ & & $\mathrm{X}$ & $\mathrm{X}$ & $\mathrm{X}$ & & $\mathrm{X}$ & $\mathrm{X}$ & $\mathrm{X}$ & $\mathrm{X}$ & $\mathrm{X}$ & $\mathrm{X}$ & & $\mathrm{X}$ & & & $\mathrm{X}$ & $\mathrm{X}$ & & $\mathrm{X}$ \\
\hline $\mathrm{E}+/ \mathrm{C}-$ & & $\mathrm{X}$ & $\mathrm{X}$ & & $\mathrm{X}$ & $\mathrm{X}$ & $\mathrm{X}$ & $\mathrm{X}$ & $\mathrm{X}$ & $\mathrm{X}$ & & $\mathrm{X}$ & $\mathrm{X}$ & $\mathrm{X}$ & & $\mathrm{X}$ & $\mathrm{X}$ & $\mathrm{X}$ & $\mathrm{X}$ & $\mathrm{X}$ & $\mathrm{X}$ & & $\mathrm{X}$ & $\mathrm{X}$ & $\mathrm{X}$ & $\mathrm{X}$ & $\mathrm{X}$ & & $\mathrm{X}$ \\
\hline SIA 2040 & & $\mathrm{X}$ & $\mathrm{X}$ & & $\mathrm{X}$ & $\mathrm{X}$ & $\mathrm{X}$ & $\mathrm{X}$ & $\mathrm{X}$ & $\mathrm{X}$ & & $\mathrm{X}$ & $\mathrm{X}$ & $\mathrm{X}$ & & & $\mathrm{X}$ & $\mathrm{X}$ & & $\mathrm{X}$ & $\mathrm{X}$ & & $\mathrm{X}$ & & & & $(\mathrm{X})$ & & \\
\hline $\mathrm{BNB}$ & & $\mathrm{X}$ & $\mathrm{X}$ & & $\mathrm{X}$ & $\mathrm{X}$ & $\mathrm{X}$ & $\mathrm{X}$ & $\mathrm{X}$ & $\mathrm{X}$ & & $\mathrm{X}$ & $\mathrm{X}$ & $\mathrm{X}$ & & $\mathrm{X}$ & $\mathrm{X}$ & $\mathrm{X}$ & $\mathrm{X}$ & $\mathrm{X}$ & $\mathrm{X}$ & & $\mathrm{X}$ & $\mathrm{X}$ & $\mathrm{X}$ & $\mathrm{X}$ & $\mathrm{X}$ & & \\
\hline BREEAM & & $\mathrm{X}$ & $\mathrm{X}$ & & $\mathrm{X}$ & $\mathrm{X}$ & $\mathrm{X}$ & $\mathrm{X}$ & $\mathrm{X}$ & $\mathrm{X}$ & & $\mathrm{X}$ & $\mathrm{X}$ & $\mathrm{X}$ & & & & & & & & & & & & & $\mathrm{X}$ & & $\mathrm{X}$ \\
\hline CASBEE & \multicolumn{29}{|c|}{ Not specified } \\
\hline DGNB & & $\mathrm{X}$ & $\mathrm{X}$ & & $\mathrm{X}$ & $\mathrm{X}$ & $\mathrm{X}$ & & $\mathrm{X}$ & & & $\mathrm{X}$ & $\mathrm{X}$ & $\mathrm{X}$ & & & & & $\mathrm{X}$ & $\mathrm{X}$ & $\mathrm{X}$ & & & & & & & & \\
\hline LEED & \multicolumn{29}{|c|}{ Not specified $^{\mathrm{a}}$} \\
\hline Brejnrod et al. 2017 & & $\mathrm{X}$ & $\mathrm{X}$ & & $\mathrm{X}$ & $\mathrm{X}$ & $\mathrm{X}$ & & $\mathrm{X}$ & & & $\mathrm{X}$ & & $\mathrm{X}$ & & & & & & & & & & & & & & & \\
\hline Chandrakumar et al. 2019 & \multicolumn{29}{|c|}{ Not specified } \\
\hline Gervasio and Dimova 2018 & & $\mathrm{X}$ & $\mathrm{X}$ & & $\mathrm{X}$ & $\mathrm{X}$ & $\mathrm{X}$ & & $\mathrm{X}$ & $\mathrm{X}$ & & & & & & & & & & & & & & & & & & & \\
\hline König 2008 & & $\mathrm{X}$ & $\mathrm{X}$ & & $\mathrm{X}$ & $\mathrm{X}$ & $\mathrm{X}$ & $\mathrm{X}$ & $\mathrm{X}$ & $\mathrm{X}$ & & $\mathrm{X}$ & $\mathrm{X}$ & $\mathrm{X}$ & & $\mathrm{X}$ & $\mathrm{X}$ & $\mathrm{X}$ & $\mathrm{X}$ & $\mathrm{X}$ & $\mathrm{X}$ & & $\mathrm{X}$ & $\mathrm{X}$ & $\mathrm{X}$ & $\mathrm{X}$ & & & \\
\hline König and De Cristofaro 2012 & \multicolumn{29}{|c|}{ Not specified } \\
\hline Lasvaux et al. 2017 & & $\mathrm{X}$ & $\mathrm{X}$ & & $\mathrm{X}$ & $\mathrm{X}$ & $\mathrm{X}$ & $\mathrm{X}$ & $\mathrm{X}$ & $\mathrm{X}$ & & $\mathrm{X}$ & $\mathrm{X}$ & $\mathrm{X}$ & & $\mathrm{X}$ & $\mathrm{X}$ & $\mathrm{X}$ & $\mathrm{X}$ & $\mathrm{X}$ & $\mathrm{X}$ & & $\mathrm{X}$ & $\mathrm{X}$ & $\mathrm{X}$ & $\mathrm{X}$ & $\mathrm{X}$ & & $\mathrm{X}$ \\
\hline Lavagna et al. 2018 & & $\mathrm{X}$ & $\mathrm{X}$ & & $\mathrm{X}$ & $\mathrm{X}$ & $\mathrm{X}$ & $\mathrm{X}$ & $\mathrm{X}$ & $\mathrm{X}$ & & $\mathrm{X}$ & & $\mathrm{X}$ & & $\mathrm{X}$ & $\mathrm{X}$ & & $\mathrm{X}$ & $\mathrm{X}$ & & & $\mathrm{X}$ & & & & $\mathrm{X}$ & & \\
\hline
\end{tabular}




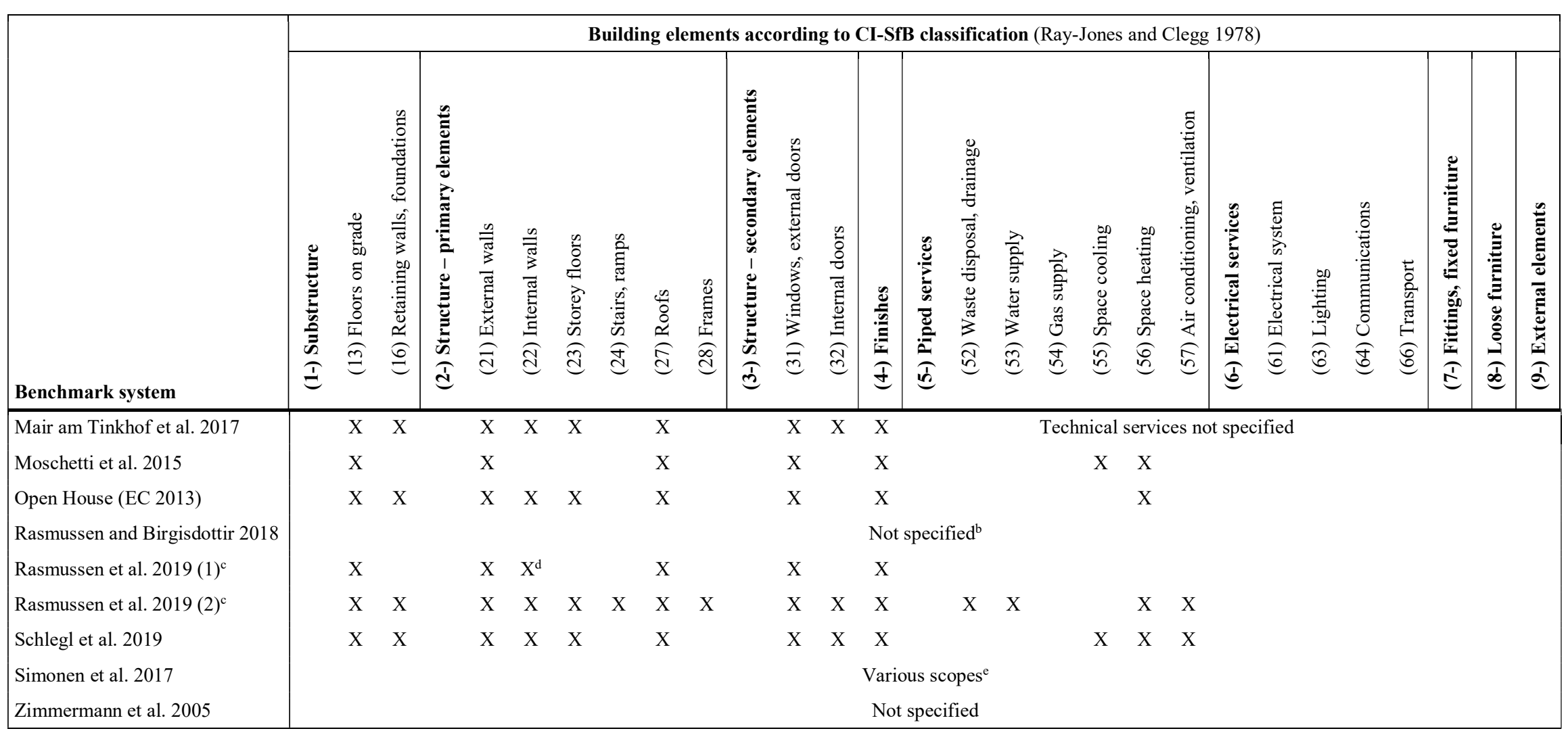

a The scope includes the structure and enclosure.

${ }^{b}$ The scope includes the foundation, structure and surfaces as well as technical aggregates.

${ }^{c}$ The study includes a comparison of benchmarks for residential buildings in Northern Italy (1) and Denmark (2).

d Only internal walls between heated and unheated spaces

${ }^{\mathrm{e}}$ The benchmark values are based on the compilation of results from existing LCA studies. Depending on the study, the scope can be limited to the structure or cover the structure, foundation, enclosure and interiors. 
Table 5 Definition of benchmark values.

\begin{tabular}{|c|c|c|c|c|}
\hline Benchmark system & $\begin{array}{l}\text { Comparative } \\
\text { base }\end{array}$ & $\begin{array}{l}\text { Benchmark } \\
\text { approach }\end{array}$ & Benchmark typology & Sources for benchmark \\
\hline MPG & External & Bottom-up & Limit value & $\begin{array}{l}\text { Statistical analysis of } 5 \text { virtual residential buildings and } 1200 \text { variants } \\
\text { (dimensions, material and technical choices) (W/E adviseurs 2014) }\end{array}$ \\
\hline $\mathrm{E}+/ \mathrm{C}-$ & External & Bottom-up & $\begin{array}{l}\text { Reference (Carbon level 1) and best practice } \\
\text { values (Carbon level 2) }\end{array}$ & $\begin{array}{l}\text { Statistical analysis of } 115 \text { real buildings including various functions, climate } \\
\text { zones, construction types and energy performances (Lebert et al. 2013) }\end{array}$ \\
\hline SIA 2040 & External & $\begin{array}{l}\text { Top down and } \\
\text { bottom-up }\end{array}$ & $\begin{array}{l}\text { Target (whole life cycle) and reference values } \\
\text { (embodied, energy use and user transport) }\end{array}$ & $\begin{array}{l}\text { 2000W Society goals for } 2050 \text { (top-down) and scenario analysis (bottom-up) } \\
\text { (SIA 2018) }\end{array}$ \\
\hline BNB & External & Bottom-up & Limit, reference and target values & $\begin{array}{l}\text { Statistical analysis of } 3 \text { virtual office buildings and } 42 \text { variants (spatial } \\
\text { concept, number of floors, glazing percentage, insulation level, type of } \\
\text { materials and technical installations) (Landgraf et al. 2015) }\end{array}$ \\
\hline BREEAM & External & Bottom-up & Benchmark scale for score allocation & Statistical analysis of buildings \\
\hline CASBEE & Internal & Not applicable & Not applicable & Comparison with a reference building \\
\hline DGNB & External & Bottom-up & $\begin{array}{l}\text { Limit, reference and } 2 \text { types of target values } \\
\text { (standard and over fulfilment) }\end{array}$ & $\begin{array}{l}\text { Statistical analysis of real office buildings (König 2008), results of DGNB } \\
\text { certifications and long-term DGNB objectives }\end{array}$ \\
\hline LEED & Internal & Not applicable & Not applicable & $\begin{array}{l}\text { Comparison with a baseline building (building with comparable size, } \\
\text { function, orientation and energy performance) }\end{array}$ \\
\hline Brejnrod et al. 2017 & External & Top-down & Target values & $\begin{array}{l}\text { Earth environmental carrying capacity allocated to buildings (based on } \\
\text { economic allocation) }\end{array}$ \\
\hline Chandrakumar et al. 2019 & External & Top-down & Target values & $\begin{array}{l}2^{\circ} \mathrm{C} \text { global carbon budget allocated to buildings (based on environmental } \\
\text { pressure allocation) }\end{array}$ \\
\hline Gervasio and Dimova 2018 & External & Bottom-up & Reference and best practice values & $\begin{array}{l}\text { Statistical analysis of } 72 \text { building models ( } 53 \text { existing and } 19 \text { new } \\
\text { residential buildings) in } 3 \text { main European climate zones }\end{array}$ \\
\hline König 2008 & External & Bottom-up & Limit, reference and target values & Statistical analysis of real office buildings from the LEGEP database \\
\hline $\begin{array}{l}\text { König and De Cristofaro } \\
2012\end{array}$ & External & Bottom-up & Limit, reference and target values & $\begin{array}{l}\text { Statistical analysis of } 13 \text { virtual residential buildings and } 39 \text { variants (energy } \\
\text { demand level, construction method and heating system) }\end{array}$ \\
\hline Lasvaux et al. $2017^{\mathrm{a}}$ & External & Bottom-up & Reference values & $\begin{array}{l}\text { Statistical analysis of } 40 \text { real low-energy single family houses including } \\
\text { various construction types and climate zones }\end{array}$ \\
\hline Lavagna et al. 2018 & External & Bottom-up & Reference values & $\begin{array}{l}\text { Statistical analysis of } 24 \text { dwelling archetypes, representative for the EU } \\
\text { housing stock (clustered according to typology, climate zone and period of } \\
\text { construction) }\end{array}$ \\
\hline
\end{tabular}




\begin{tabular}{|c|c|c|c|c|}
\hline Benchmark system & $\begin{array}{l}\text { Comparative } \\
\text { base }\end{array}$ & $\begin{array}{l}\text { Benchmark } \\
\text { approach }\end{array}$ & Benchmark typology & Sources for benchmark \\
\hline Mair am Tinkhof et al. 2017 & External & $\begin{array}{l}\text { Top-down and } \\
\text { bottom-up }\end{array}$ & $\begin{array}{l}\text { Target (whole life cycle) and reference values } \\
\text { (embodied, energy use and user transport) }\end{array}$ & $\begin{array}{l}\text { Austrian primary energy and } \mathrm{CO} 2 \text { reduction targets (top-down) and } \\
\text { statistical analysis of } 9 \text { representative buildings and } 22 \text { variants (construction } \\
\text { type, technical system and energy performance) (bottom-up) }\end{array}$ \\
\hline Moschetti et al. 2015 & External & Bottom-up & Reference values & $\begin{array}{l}\text { Statistical analysis of } 4 \text { residential building archetypes and } 36 \text { variants } \\
\text { (climate zone and building system) }\end{array}$ \\
\hline Open House (EC 2013) & External & Bottom-up & Limit, reference and target values & Statistical analysis of 6 case studies \\
\hline $\begin{array}{l}\text { Rasmussen and Birgisdottir } \\
2018\end{array}$ & External & Bottom-up & Reference values & Statistical analysis of 16 real office buildings \\
\hline Rasmussen et al. 2019 & External & Bottom-up & Reference values & $\begin{array}{l}\text { Statistical analysis of real residential buildings ( } 28 \text { buildings with the Italian } \\
\text { CasaClima Nature certification and } 7 \text { buildings with the Danish DGNB } \\
\text { certification) }\end{array}$ \\
\hline Schlegl et al. 2019 & External & Bottom-up & Reference values & Statistical analysis of 22 real office buildings from the DGNB database \\
\hline Simonen et al. 2017 & External & Bottom-up & Reference values & Statistical analysis of results from existing LCA databases and studies \\
\hline Zimmermann et al. 2005 & External & Top-down & Target values & $\begin{array}{l}\text { Permissible loads calculated based on the ecological scarcity method, GHG } \\
\text { reduction targets and } 2000 \mathrm{~W} \text { Society goals (using a combination of } \\
\text { environmental pressure and economic allocation) }\end{array}$ \\
\hline
\end{tabular}


Table 6 Benchmark scope - life cycle stages.

\begin{tabular}{|c|c|c|c|c|c|c|c|c|c|c|c|c|c|c|c|c|c|c|c|c|c|c|}
\hline \multirow[b]{2}{*}{ Benchmark system } & \multicolumn{5}{|c|}{ Main categories } & \multicolumn{15}{|c|}{ Life cycle modules according to EN 15804:2012+A2 (CEN 2019) } & \multicolumn{2}{|c|}{$\begin{array}{c}\text { Other } \\
\text { modules }\end{array}$} \\
\hline & 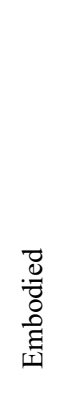 & 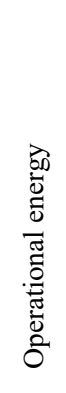 & 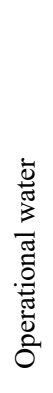 & 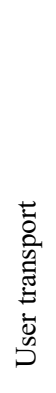 & 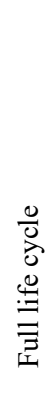 & 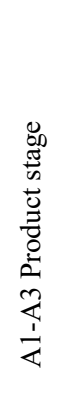 & 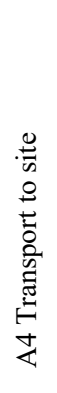 & 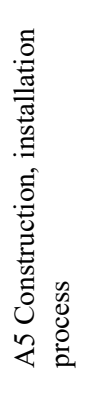 & $\begin{array}{l}\stackrel{D}{D} \\
\vec{n}\end{array}$ & 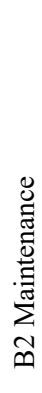 & 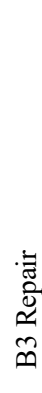 & 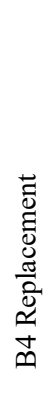 & 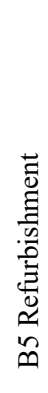 & 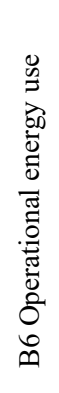 & 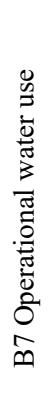 & 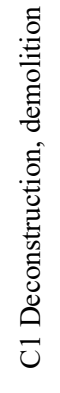 & 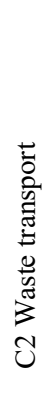 & 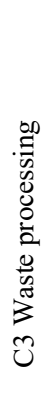 & 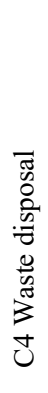 & 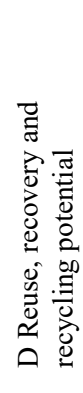 & 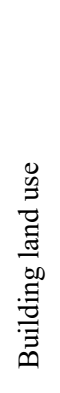 & 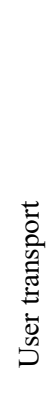 \\
\hline MPG & $\mathrm{X}$ & & & & & $\mathrm{X}$ & $\mathrm{X}$ & $\mathrm{X}$ & $\mathrm{X}$ & $\mathrm{X}$ & $\mathrm{X}$ & $\mathrm{X}$ & & & & $\mathrm{X}$ & $\mathrm{X}$ & $\mathrm{X}$ & $\mathrm{X}$ & $\mathrm{X}$ & & \\
\hline $\mathrm{E}+/ \mathrm{C}-$ & $\mathrm{X}$ & & & & $\mathrm{X}$ & $\mathrm{X}$ & $\mathrm{X}$ & $\mathrm{X}$ & $\mathrm{X}$ & $\mathrm{X}$ & $\mathrm{X}$ & $\mathrm{X}$ & $\mathrm{X}$ & $\mathrm{X}$ & $\mathrm{X}$ & $\mathrm{X}$ & $\mathrm{X}$ & $\mathrm{X}$ & $\mathrm{X}$ & $\mathrm{X}$ & & \\
\hline SIA 2040 & $\mathrm{x}$ & $\mathrm{x}$ & & $\mathrm{x}$ & $\mathrm{X}$ & $\mathrm{X}$ & & & & & & $\mathrm{X}$ & & $\mathrm{X}$ & & $\mathrm{X}$ & $\mathrm{X}$ & $X$ & $\mathrm{X}$ & & & $\mathrm{X}$ \\
\hline $\mathrm{BNB}$ & $(\mathrm{x})^{\mathrm{a}}$ & $(\mathrm{x})^{\mathrm{a}}$ & & & $\mathrm{X}$ & $\mathrm{X}$ & & & & $\mathrm{X}$ & & $\mathrm{X}$ & & $\mathrm{X}$ & & & & $\mathrm{X}$ & $\mathrm{X}$ & & & \\
\hline BREEAM & $\mathrm{X}$ & & & & & & & & & & & & & speci & & & & & & & & \\
\hline CASBEE & & & & & $\mathrm{X}$ & & & & & & & & & speci & & & & & & & & \\
\hline DGNB & $\mathrm{x}$ & $\mathrm{x}$ & & & $\mathrm{X}$ & $\mathrm{X}$ & & & & & & $\mathrm{X}$ & & $\mathrm{X}$ & & & & $\mathrm{X}$ & $\mathrm{X}$ & $\mathrm{X}$ & & \\
\hline LEED & & & & & $\mathrm{X}$ & & & & & & & & & speci & & & & & & & & \\
\hline Brejnrod et al. 2017 & & & & & $\mathrm{X}$ & $\mathrm{X}$ & $\mathrm{X}$ & $\mathrm{X}$ & & & $\mathrm{X}$ & $\mathrm{X}$ & & $X$ & & $\mathrm{X}$ & $\mathrm{X}$ & $X$ & $\mathrm{X}$ & $\mathrm{X}$ & $\mathrm{X}$ & \\
\hline Chandrakumar et al. 2019 & $\mathrm{x}$ & $\mathrm{x}$ & $\mathrm{x}$ & & $\mathrm{X}$ & $\mathrm{X}$ & $\mathrm{X}$ & $\mathrm{X}$ & & $\mathrm{X}$ & & $\mathrm{X}$ & & $\mathrm{X}$ & $\mathrm{X}$ & $\mathrm{X}$ & $\mathrm{X}$ & $\mathrm{X}$ & $\mathrm{X}$ & & & \\
\hline Gervasio and Dimova 2018 & $X$ & & & & & $\mathrm{X}$ & & & & & & $\mathrm{X}$ & & & & $\mathrm{X}$ & $\mathrm{X}$ & $\mathrm{X}$ & $\mathrm{X}$ & $\mathrm{X}$ & & \\
\hline König 2008 & $(\mathrm{x})^{\mathrm{c}}$ & $(\mathrm{x})^{\mathrm{c}}$ & & & $\mathrm{X}$ & $\mathrm{X}$ & & $\mathrm{X}$ & & & & $\mathrm{X}$ & & $\mathrm{X}$ & & $\mathrm{X}$ & & & $\mathrm{X}$ & & & \\
\hline König and De Cristofaro 2012 & & & & & $\mathrm{X}$ & $\mathrm{X}$ & & & & & & $\mathrm{X}$ & & $\mathrm{X}$ & & & & & $\mathrm{X}$ & & & \\
\hline Lasvaux et al. 2017 & $\mathrm{X}$ & $\mathrm{X}$ & $\mathrm{X}$ & & $\mathrm{X}$ & $\mathrm{X}$ & $\mathrm{X}$ & $\mathrm{X}$ & & $\mathrm{X}$ & & $\mathrm{X}$ & & $\mathrm{X}$ & $\mathrm{X}$ & & $\mathrm{X}$ & $\mathrm{X}$ & $\mathrm{X}$ & & & \\
\hline Lavagna et al. 2018 & $\mathrm{x}$ & $x^{d}$ & $\mathrm{x}^{\mathrm{d}}$ & & $\mathrm{X}$ & $\mathrm{X}$ & $\mathrm{X}$ & $\mathrm{X}$ & & & & $\mathrm{X}$ & & $\mathrm{X}$ & $\mathrm{X}$ & $\mathrm{X}$ & $\mathrm{X}$ & $\mathrm{X}$ & $\mathrm{X}$ & $\mathrm{X}$ & & \\
\hline Mair am Tinkhof et al. 2017 & $\mathrm{x}$ & $\mathrm{x}$ & & $\mathrm{x}$ & $\mathrm{X}$ & $\mathrm{X}$ & & & & & & $\mathrm{X}$ & & $\mathrm{X}$ & & $\mathrm{X}$ & $\mathrm{X}$ & $\mathrm{X}$ & $\mathrm{X}$ & & & $\mathrm{X}$ \\
\hline
\end{tabular}




\begin{tabular}{|c|c|c|c|c|c|c|c|c|c|c|c|c|c|c|c|c|c|c|c|c|c|c|}
\hline \multirow[b]{2}{*}{ Benchmark system } & \multicolumn{5}{|c|}{ Main categories } & \multicolumn{15}{|c|}{ Life cycle modules according to EN 15804:2012+A2 (CEN 2019) } & \multicolumn{2}{|c|}{$\begin{array}{c}\text { Other } \\
\text { modules }\end{array}$} \\
\hline & 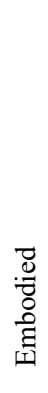 & 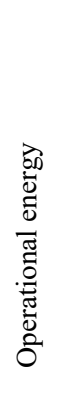 & 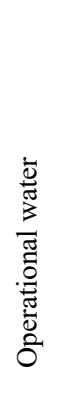 & 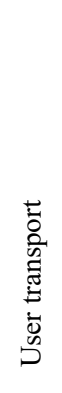 & 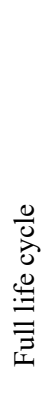 & 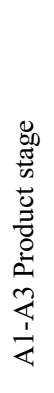 & 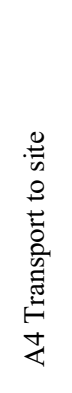 & 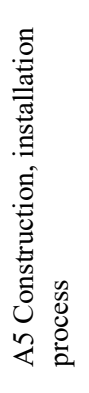 & $\begin{array}{l}0 \\
\ddot{n} \\
\vec{n}\end{array}$ & 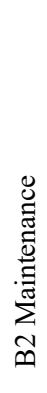 & 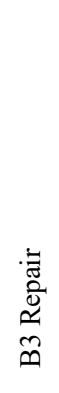 & 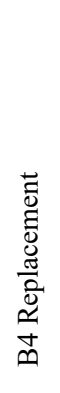 & 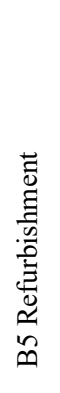 & 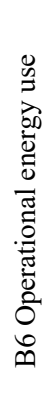 & 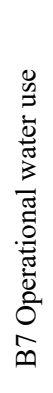 & 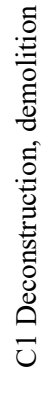 & 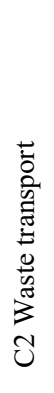 & 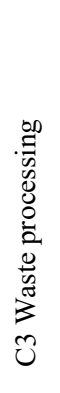 & 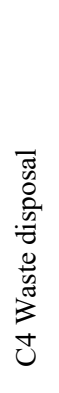 & 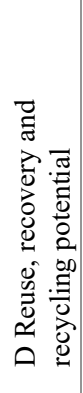 & 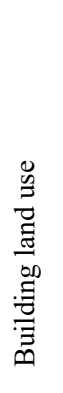 & 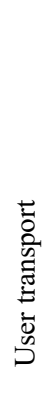 \\
\hline Moschetti et al. 2015 & $\mathrm{X}$ & $\mathrm{X}^{\mathrm{d}}$ & $X^{d}$ & & $\mathrm{X}$ & $\mathrm{X}$ & $\mathrm{X}$ & $\mathrm{X}$ & & $\mathrm{X}$ & & $\mathrm{X}$ & & $\mathrm{X}$ & $\mathrm{X}$ & $\mathrm{X}$ & $\mathrm{X}$ & $\mathrm{X}$ & $\mathrm{X}$ & & & \\
\hline Open House (EC 2013) & $\mathrm{x}$ & $\mathrm{x}$ & & & $\mathrm{X}$ & $\mathrm{X}$ & & & $\mathrm{X}$ & & & $\mathrm{X}$ & & $\mathrm{X}$ & & & & $\mathrm{X}$ & $\mathrm{X}$ & $\mathrm{X}$ & & \\
\hline Rasmussen and Birgisdottir 2018 & $\mathrm{X}$ & $\mathrm{X}$ & & & & $\mathrm{X}$ & & & & & & $\mathrm{X}$ & & $\mathrm{X}$ & & & & $\mathrm{X}$ & $\mathrm{X}$ & & & \\
\hline Rasmussen et al. $2019(1)^{\mathrm{e}}$ & & & & & & $\mathrm{X}$ & $\mathrm{X}$ & $\mathrm{X}$ & & & & $\mathrm{X}$ & & $\mathrm{X}$ & $\mathrm{X}$ & & $\mathrm{X}$ & $\mathrm{X}$ & $\mathrm{X}$ & & & \\
\hline Rasmussen et al. $2019(2)^{\mathrm{e}}$ & & & & & & $\mathrm{X}$ & & & & & & $\mathrm{X}$ & & $\mathrm{X}$ & & & & $\mathrm{X}$ & $\mathrm{X}$ & & & \\
\hline Schlegl et al. 2019 & $\mathrm{X}$ & $\mathrm{X}$ & & & $\mathrm{X}$ & $\mathrm{X}$ & & & & & & $\mathrm{X}$ & & $\mathrm{X}$ & & & & $\mathrm{X}$ & $\mathrm{X}$ & $\mathrm{X}$ & & \\
\hline Simonen et al. 2017 & $\mathrm{X}$ & & & & & $\mathrm{X}$ & $(X)^{f}$ & $(X)^{f}$ & & & & & & & & & & & & & & \\
\hline Zimmermann et al. 2005 & $\mathrm{x}$ & $\mathrm{x}$ & & & $\mathrm{X}$ & & & & & & & & & peci & & & & & & & & \\
\hline
\end{tabular}

$\mathrm{X}=$ main benchmark values; $\mathrm{x}=$ indicative benchmark values

${ }^{\text {a }}$ Benchmark values for embodied impacts and operational energy use are only available for laboratories.

${ }^{\mathrm{b}}$ CASBEE considers three main stages: Construction, Maintenance/Upgrade/Demolition and Operation. There is no further specification of the included life cycle modules.

" Benchmark values for embodied impacts and operational energy use are only available for the indicator "Primary energy demand".

d Benchmark value for the impact of operational energy and water use together

${ }^{\mathrm{e}}$ The study includes a comparison of benchmarks for residential buildings in Northern Italy (1) and Denmark (2).

${ }^{\mathrm{f}}$ The benchmark values are based on the compilation of results from existing LCA studies. Depending on the study, the impact of the construction stage (A4-A5) may be included or not.

${ }^{\mathrm{g}}$ The following stages are considered: construction/ refurbishment, heating/hot water and electricity. There is no further specification of the included life cycle modules. 
Table 7 Benchmark scope - environmental indicators.

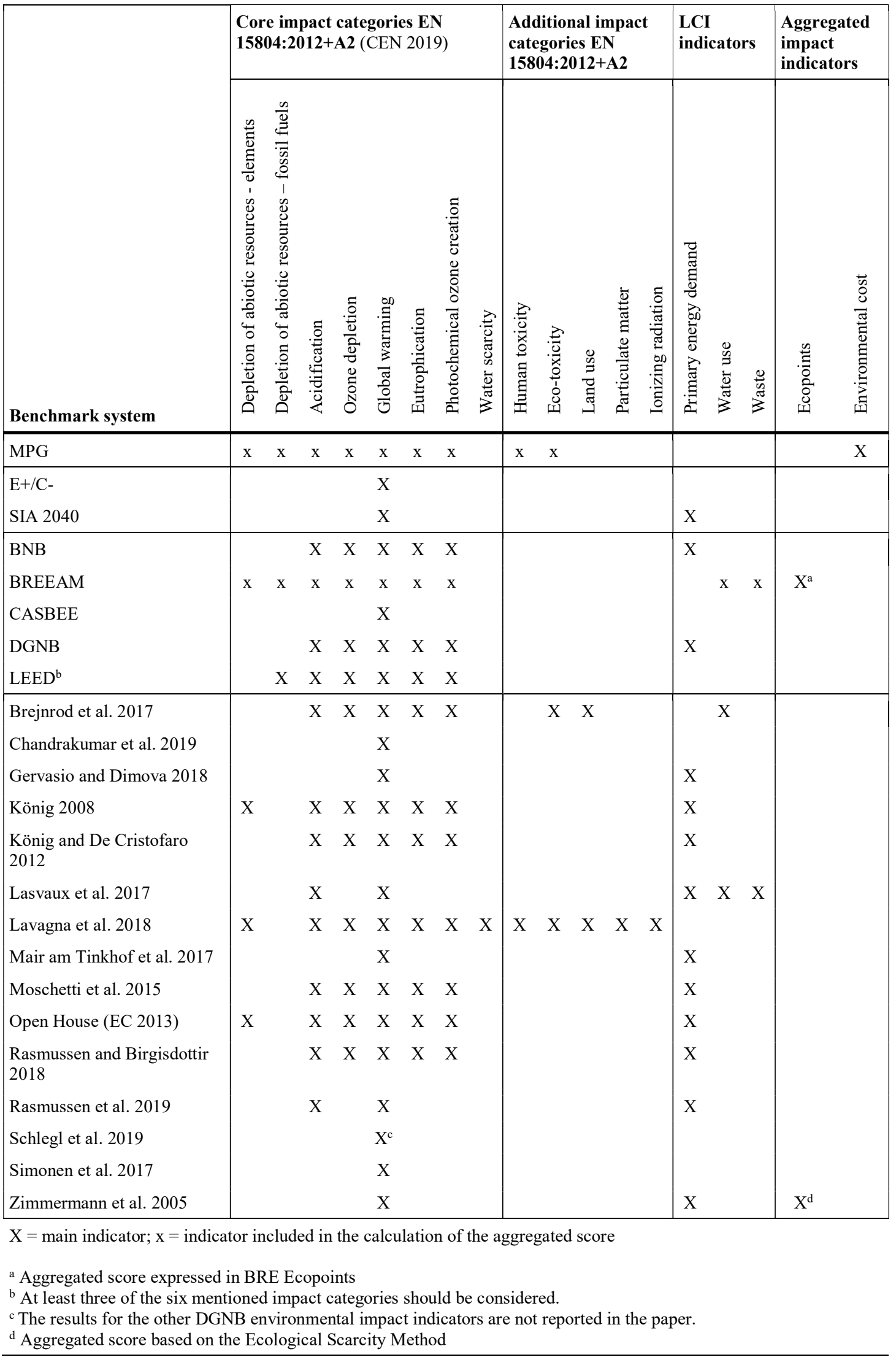


Table 8 Benchmark applications.

\begin{tabular}{|c|c|c|c|c|c|c|c|c|c|c|c|c|}
\hline & \multicolumn{9}{|c|}{ Building types } & \multicolumn{3}{|c|}{$\begin{array}{c}\text { Type of } \\
\text { construction works }\end{array}$} \\
\hline Benchmark system & 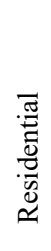 & 导 & 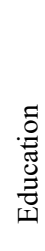 & 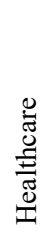 & 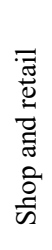 & 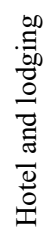 & 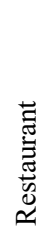 & 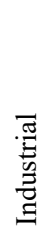 & $\stackrel{\bar{\Xi}}{\overline{0}}$ & 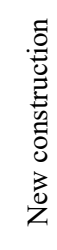 & 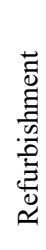 & 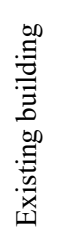 \\
\hline MPG & $\mathrm{X}$ & $\mathrm{X}$ & & & & & & & & $\mathrm{X}$ & & \\
\hline $\mathrm{E}+/ \mathrm{C}-$ & $\mathrm{X}$ & $\mathrm{X}$ & $\mathrm{X}$ & $\mathrm{X}$ & $\mathrm{X}$ & $\mathrm{X}$ & $\mathrm{X}$ & $\mathrm{X}$ & $\mathrm{X}^{\mathrm{a}}$ & $\mathrm{X}$ & & \\
\hline SIA 2040 & $\mathrm{X}$ & $\mathrm{X}$ & $\mathrm{X}$ & & $\mathrm{X}$ & & $\mathrm{X}$ & & & $\mathrm{X}$ & $\mathrm{X}$ & \\
\hline BNB & & $\mathrm{X}$ & $\mathrm{X}$ & & & & & & $\mathrm{X}^{\mathrm{b}}$ & $\mathrm{X}$ & & \\
\hline BREEAM & $\mathrm{X}$ & & & & & & & & & $\mathrm{X}$ & & \\
\hline CASBEE & $\mathrm{X}$ & $\mathrm{X}$ & $\mathrm{X}$ & $\mathrm{X}$ & $\mathrm{X}$ & $\mathrm{X}$ & $\mathrm{X}$ & $\mathrm{X}$ & $X^{c}$ & $\mathrm{X}$ & & \\
\hline DGNB & $\mathrm{X}$ & $\mathrm{X}$ & $\mathrm{X}$ & & $\mathrm{X}$ & $\mathrm{X}$ & & $\mathrm{X}$ & & $\mathrm{X}$ & & \\
\hline LEED & $\mathrm{X}$ & $\mathrm{X}$ & $\mathrm{X}$ & $\mathrm{X}$ & $\mathrm{X}$ & $\mathrm{X}$ & & $\mathrm{X}$ & $X^{d}$ & $\mathrm{X}$ & & \\
\hline Brejnrod et al. 2017 & $\mathrm{X}$ & & & & & & & & & $\mathrm{X}$ & & \\
\hline Chandrakumar et al. 2019 & $\mathrm{X}$ & & & & & & & & & $\mathrm{X}$ & & \\
\hline Gervasio and Dimova 2018 & $\mathrm{X}$ & & & & & & & & & $\mathrm{X}$ & & $\mathrm{X}$ \\
\hline König 2008 & & $\mathrm{X}$ & & & & & & & & $\mathrm{X}$ & & \\
\hline $\begin{array}{l}\text { König and De Cristofaro } \\
2012\end{array}$ & $\mathrm{X}$ & & & & & & & & & $\mathrm{X}$ & & \\
\hline Lasvaux et al. 2017 & $\mathrm{X}$ & & & & & & & & & $\mathrm{X}$ & & \\
\hline Lavagna et al. 2018 & $\mathrm{X}$ & & & & & & & & & & & $\mathrm{X}$ \\
\hline Mair am Tinkhof et al. 2017 & $\mathrm{X}$ & $\mathrm{X}$ & $\mathrm{X}$ & & & & & & & $\mathrm{X}$ & & \\
\hline Moschetti et al. 2015 & $\mathrm{X}$ & & & & & & & & & $X$ & & \\
\hline Open House (EC 2013) & & $\mathrm{X}$ & & & & & & & & $\mathrm{X}$ & & \\
\hline $\begin{array}{l}\text { Rasmussen and Birgisdottir } \\
2018\end{array}$ & & $\mathrm{X}$ & & & & & & & & $\mathrm{X}$ & & \\
\hline Rasmussen et al. 2019 & $\mathrm{X}$ & & & & & & & & & $\mathrm{X}$ & & \\
\hline Schlegl et al. 2019 & & $\mathrm{X}$ & & & & & & & & $\mathrm{X}$ & & \\
\hline Simonen et al. 2017 & $\mathrm{X}$ & $\mathrm{X}$ & $\mathrm{X}$ & $\mathrm{X}$ & $\mathrm{X}$ & $\mathrm{X}$ & & & $\mathrm{X}$ & $\mathrm{X}$ & & \\
\hline Zimmermann et al. 2005 & $\mathrm{X}$ & $\mathrm{X}$ & & & & & & & & $\mathrm{X}$ & $\mathrm{X}$ & \\
\hline
\end{tabular}

a Other buildings which are subject to the energy regulations

${ }^{b}$ Laboratories

${ }^{c}$ Halls and lobbies

${ }^{\mathrm{d}}$ Data centres 
Table 9 Benchmark communication.

\begin{tabular}{|c|c|c|c|c|}
\hline Benchmark system & 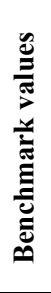 & 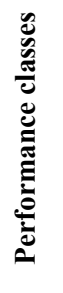 & : & Description \\
\hline MPG & $\mathrm{X}$ & $\mathrm{X}$ & & $\begin{array}{l}\text { Maximum environmental cost of } 1 \text { euro } / \mathrm{m}^{2} \text {.year and } 5 \text { performance classes } \\
\text { (from A to E) }\end{array}$ \\
\hline $\begin{array}{l}\text { E+/C- } \\
\text { SIA } 2040\end{array}$ & $\mathrm{X}$ & $\mathrm{X}$ & & 2 performance classes: Carbon level 1 and Carbon level 2 \\
\hline BNB & & & $\mathrm{X}$ & Score based on interpolation between limit, reference and target values \\
\hline BREEAM & & & $\mathrm{X}$ & Score based on benchmark scale \\
\hline CASBEE & & & $\mathrm{X}$ & Score based on impact reduction compared to reference building \\
\hline DGNB & & & $\mathrm{X}$ & Score based on limit, reference and target values \\
\hline LEED & & & $\mathrm{X}$ & Score based on impact reduction compared to reference building \\
\hline Brejnrod et al. 2017 & $\mathrm{X}$ & & & \\
\hline Chandrakumar et al. 2019 & $\mathrm{X}$ & & & \\
\hline Gervasio and Dimova 2018 & $\mathrm{X}$ & & & \\
\hline König 2008 & $\mathrm{X}$ & & & \\
\hline $\begin{array}{l}\text { König and De Cristofaro } \\
2012\end{array}$ & $\mathrm{X}$ & & & \\
\hline Lasvaux et al. 2017 & $\mathrm{X}$ & & & \\
\hline Lavagna et al. 2018 & $\mathrm{X}$ & & & \\
\hline Mair am Tinkhof et al. 2017 & $\mathrm{X}$ & & & \\
\hline Moschetti et al. 2015 & $\mathrm{X}$ & & & \\
\hline Open House (EC 2013) & & & $\mathrm{X}$ & Score based on interpolation between limit, reference and target values \\
\hline $\begin{array}{l}\text { Rasmussen and Birgisdottir } \\
2018\end{array}$ & $\mathrm{X}$ & & & \\
\hline Rasmussen et al. 2019 & $\mathrm{X}$ & & & \\
\hline Schlegl et al. 2019 & $\mathrm{X}$ & & & \\
\hline Simonen et al. 2017 & $\mathrm{X}$ & & & \\
\hline Zimmermann et al. 2005 & $\mathrm{X}$ & & & \\
\hline
\end{tabular}

571 
Figures

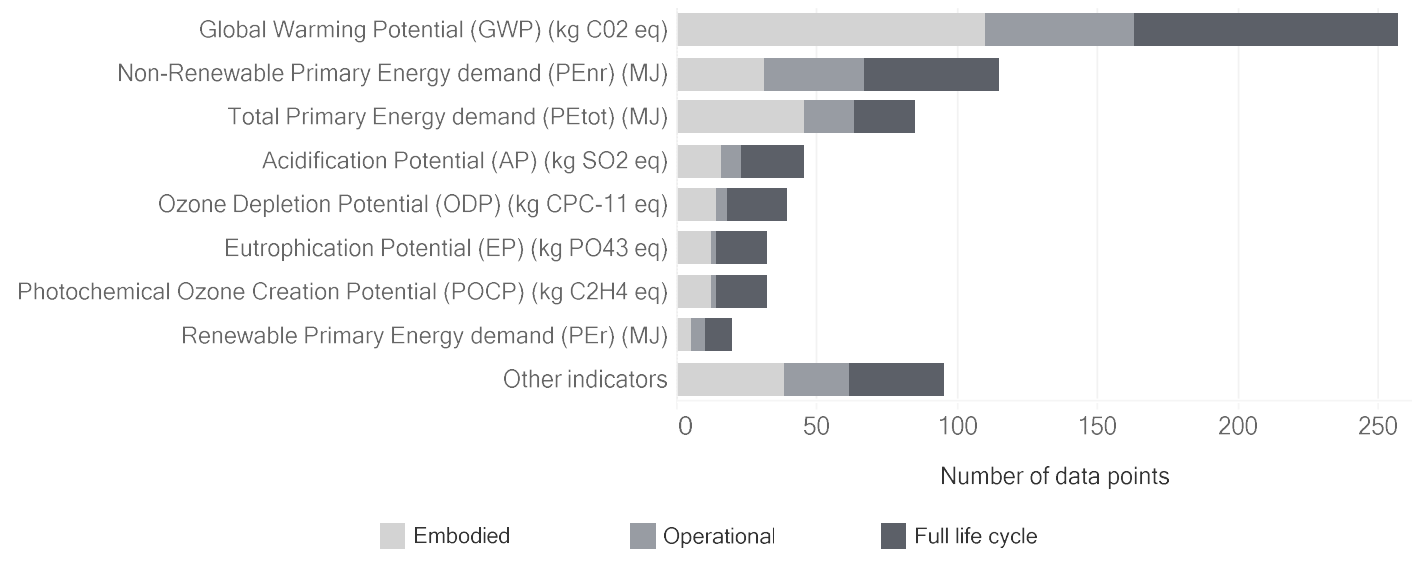

Fig. 1 Number of data points included in the benchmark database, subdivided per environmental indicator. 
Embodied impacts
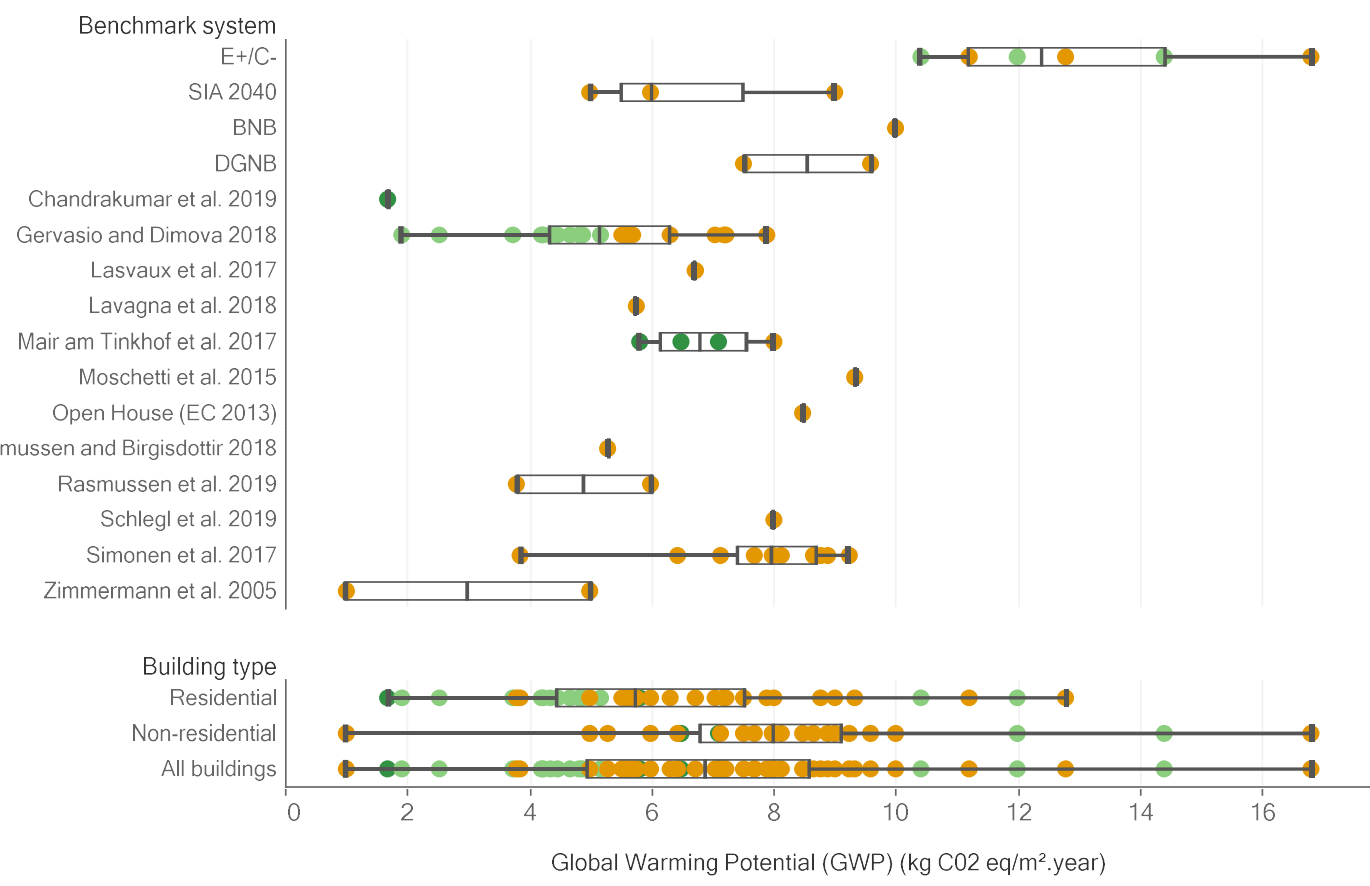

Full life cycle impacts

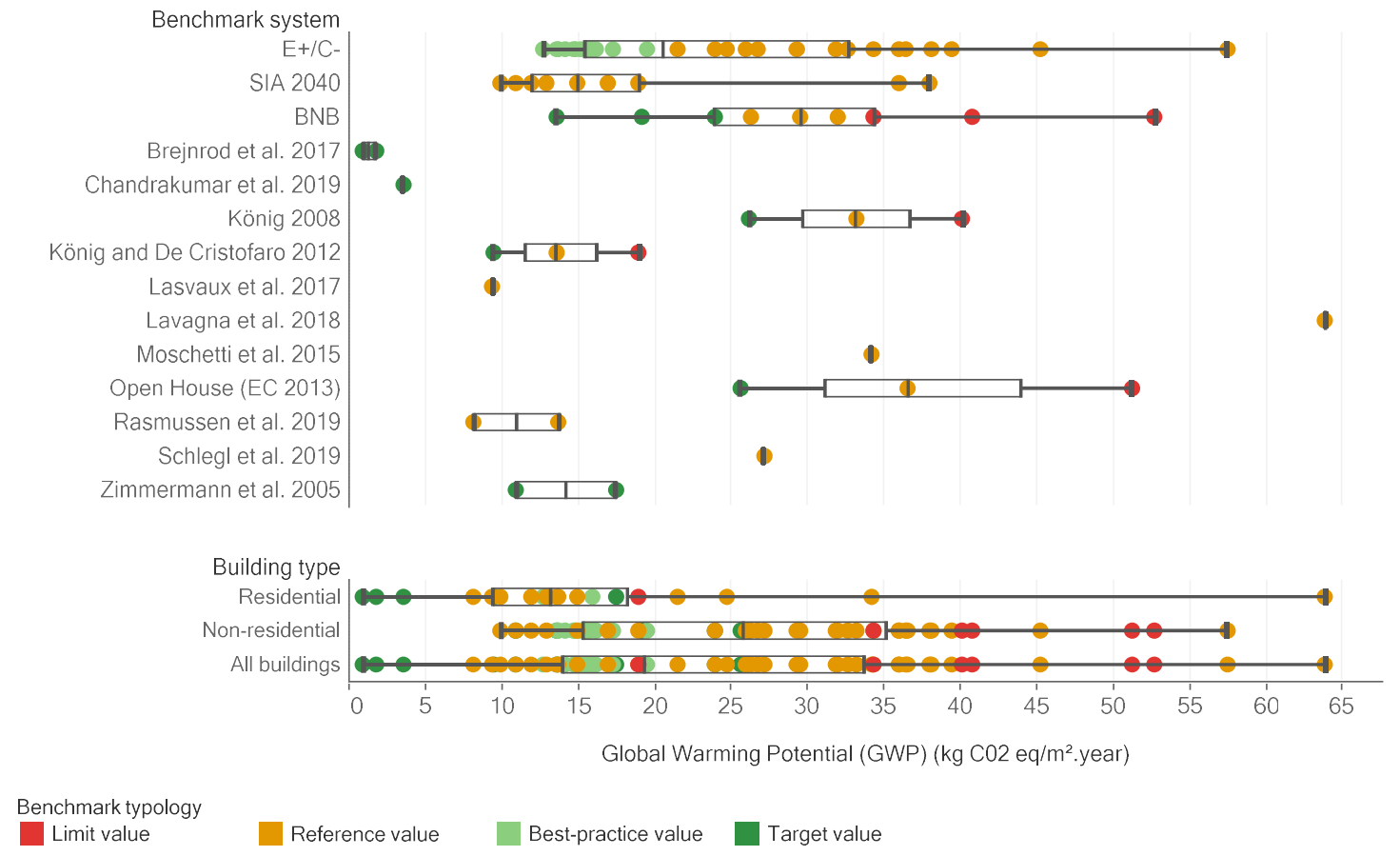

Fig. 2 Benchmark values for the Global Warming Potential (GWP), subdivided in embodied (above) and full life cycle impacts (below). 